\title{
Social Stability and Resource Allocation within Business Groups
}

\author{
Haikun $\mathrm{Zhu}^{*}$
}

Working Paper No. 79

August 1st, 2018

\begin{abstract}
Using datasets on transactions within business groups and social sentiment in China, I show that state-owned enterprises (SOEs) use internal funds to address social unrest, complying with the government's political goals. I use plausibly unexpected shocks to regional stability to analyze the response of SOEs to these events. I find that the government, as the controlling shareholder, adopts a carrot-and-stick approach. The government offers a "carrot" by injecting funds into SOEs located in the affected areas, which are then used to generate benefits to the public, such as larger labor payments and additional capital expenditures. However, if there are severe political conflicts that threaten its authority, the government applies a "stick" by withdrawing resources. The SOEs channel seems effective because local sentiment recovers around shocks when SOEs offer more benefits. Additional tests show that the SOEs channel is significant in economic magnitude compared to fiscal redistribution. As a result of the transfer, SOEs lose value after shocks, but firms in the region improve their performance later. This paper provides new evidence on how the intra-group allocation of resources incorporates political objectives, and has socioeconomic impact.
\end{abstract}

* Tilburg University and CentER, h.zhu@ @ilburguniversity.edu. 
JEL Codes: G32; G34; D74; P16

Keywords: business groups, internal capital market, political economy, social stability.

Acknowledgements: I thank Fabio Braggion, Alberto Manconi, Joost Driessen, Laurence van Lent, Nicola Pavanini, Rik Frehen, Patrick Verwijmeren, Hao Liang, Peter Cziraki, Ahmed Tahoun, participants at the EEA annual conference (Lisbon), the Finance and History workshop (Utrecht), the Finance Down Under conference (Melbourne), and seminar participants at Tilburg University, Singapore Management University, Nanyang Technological University, Central University of Finance and Economics, Shanghai University of Finance and Economics, Shanghai Advanced Institute of Finance, Erasmus University of Rotterdam, and BI Norwegian Business School for their useful comments. I am grateful to the Institute for New Economic Thinking for the financial support through the research grant \#INO16-00023. 


\section{Introduction}

The literature on the economic merits of state and private ownership provides ample evidence that state owned enterprises (SOEs) are less efficient than their private counterparts. ${ }^{1}$ These differences in efficiency have been attributed to agency problems caused by the weak incentives offered to SOE managers and by poor monitoring, as well as to politicians' rent-seeking at the expense of minority shareholders (Shleifer and Vishny (1994, 1998), Shleifer (1998)). Successive waves of privatization since the 1980s have led to a marked reduction in state ownership, yet, in the post-privatization era, SOEs continue to be among the largest corporations in the world and account for a substantial share of the economy in many countries. Furthermore, recent years have witnessed a resurgence of state ownership, especially in emerging markets (Hsu, Liang, and Matos (2017); Musacchio and Lazzarini (2014); Musacchio, Lazzarini, and Aguilera (2015)).

What functions does state ownership carry to compensate for its economic inefficiency for government shareholders? Hart and Zingales (2017) imply that such functions lie in the embedded incentives for SOEs to address governments' non-economic goals and in the government's willingness to trade short-run profits for achieving such goals. Their model shows that in the presence of shareholders who care about social issues, the function of the firms will be to maximize shareholders' welfare by internalizing non-economic goals, rather than just wealth. Such shareholders are willing to accept lower returns when a firm achieves these goals.

In this paper, I focus on the government's political goal of maintaining social stability and study whether business groups of SOEs strategically deploy resources through internal capital markets in response to regional social unrest. ${ }^{2}$ Governments value social stability. Failing to address social unrest properly could result in a government's loss of political power (Acemoglu and Robinson (2000b)) and lower economic growth (Alesina and Perotti (1996)). As controlling shareholders, governments could impose on SOEs the goal of addressing social unrest. More specifically, business groups allocate resources across their units by conducting transactions on internal capital markets. In this way, government owners can inject funds into SOEs located in regions affected by incidents of social unrest (e.g., terrorist attacks). When SOEs in such regions

\footnotetext{
${ }^{1}$ For example, Megginson, Nash, and Randenborgh (1994), La Porta and Lopez-de-Silanes (1999), Dewenter and Malatesta (2001), and Ljungqvist et al. (2017)

${ }^{2}$ A typical state-owned business group holds multiple SOEs.
} 
receive additional funds, they can use these funds to distribute benefits to local residents. Government owners may accept losses in share value when the allocative strategy in state-owned business groups restores peace.

Testing whether and how SOEs internalize the government's political goal of maintaining social stability poses three empirical challenges. First, such a test requires a direct measure of resource allocation within business groups to discover the channel through which government intervenes. Studies on business groups based on U.S. data rely largely on segment-level data (Berger and Ofek (1995); Shin and Stulz (1998); Hund, Monk, and Tice (2012)), which is collected annually and does not provide information on internal pricing. To document changes in resource allocation relative to the timing of incidents of social unrest, it is crucial to have both frequent measurements of intra-group resource flows and the pricing rules of each transaction. Price distortions, which are normally difficult to measure, are another important dimension for evaluating allocative distortions. Complicating matters further, the evidence shows that companies strategically disclose segment data to hide sensitive information (Berger and Hann (2007)).

Secondly, in order to infer a causal relationship between resource flows and social stability, exogenous variations in the likelihood of regional social unrest are needed, because government intervention and social unrest are jointly determined. In fact, the benefits offered by SOEs may invite a potential threat of unrest. Without a shock to the probability of social unrest, one cannot conclude that changes in the intra-group resource flows are caused by instability.

Thirdly, in order to show the social consequences of resource allocation in state-owned business groups, I need a proxy for social welfare. Typically, the literature either constructs proxies for social welfare using economic and demographic data (e.g., Jones and Klenow (2016)) or relies on surveys (e.g., Anderson and Guillory (1997)). However, proxies using economic and demographic data tend to introduce issues of endogeneity at the level of the firm, because economic performance is correlated with a firm's activities. Surveys often report data at the annual frequency, and it is difficult to obtain systematic fine-grained data over multiple years. Therefore, capturing the immediate change of welfare around shocks is a challenge.

I address these challenges in my empirical design by exploiting the unique features of the Chinese setting. First, I obtain deal-level data on related party transactions (RPTs) from the China Stock Market \& Accounting Research (CSMAR) database. The data records all 
transactions within Chinese business groups, which allows me directly to observe resource allocation within business groups. The China Securities Regulatory Committee (CSRC) mandates that all publicly listed firms disclose all transactions between related parties within a business group. The dataset reports pricing rules of each transaction, which enable me to differentiate transactions priced at market prices or at off-market prices. Off-market prices are mainly negotiated prices and government regulated prices that potentially involve price distortion. With all this information, I can measure resource allocation by both the amount of cash flow and the price distortion associated with each transaction. Secondly, I identify a set of arguably unanticipated adverse events that take place in different regions both within and outside of China. Examples of these events include riots over separatism, scandals involving highranking politicians, terrorist attacks, and escalating military tensions between China and Japan. While some of these events might be expected, their exact timing and location are difficult to anticipate, and it is this variation that I am using for identification. These events have the potential to disturb the balance of social unrest and government intervention in those cities where they occur, which allows me to identify the causal relation. Thirdly, I employ data compiled by Chen et al. (2015) to construct an index of local sentiment as an approximation for social welfare, based on a textual analysis of sampled posts from Weibo (a Chinese microblogging website, similar to Twitter).

The evidence shows that SOEs internalize the political goal of maintaining social stability. First, I find that resource allocation in state-owned business groups responds to regional shocks to social stability and follows a carrot-and-stick approach. On the one hand, a government responds to shocks by injecting more funds into SOEs located in areas affected by social unrest events than into SOEs in unaffected areas, through transactions in the internal capital market of the business groups. These transactions also display a higher level of price distortion that potentially benefits SOEs in affected areas. This is the "carrot" approach. The ratio of net cash inflow generated by intra-group transactions to firm assets increases 0.9 percentage points, or $14 \%$ of one standard deviation, more for SOEs in affected areas than for SOEs in unaffected areas around shocks. This effect corresponds to 543 million Chinese yuan (about US\$84 million) in additional funds in the year following a shock, equivalent to $2 \%$ of the average annual fiscal expenditure in Chinese cities in $2011 .^{3}$ Regarding the level of price distortion, the ratio of net

\footnotetext{
${ }^{3}$ The National Bureau of Statistics of China.
} 
transactions with off-market prices that bring in funds to total number of transactions increases by 7.3 percentage points, or $13 \%$ of one standard deviation, more for SOEs in affected areas than for those in unaffected areas.

On the other hand, when a government is faced with a severe political conflict that threatens its ultimate legitimacy, government applies the "stick". Around the March 14, 2008 Tibet riot and the July 5, 2009 Urumqi riot, the ratio of net cash inflow to firm assets decreases by 0.5 percentage points, or $8 \%$ of one standard deviation, more for SOEs located in Tibet, Aba and Urumqi (though the magnitude of this change is smaller than that described above). This effect corresponds to a withdrawal of funds amounting to US\$22 million. The ratio of net transactions with off-market prices to total number of transactions also decreases by 8 percentage points, or $16 \%$ of one standard deviation more for SOEs in affected areas. This carrot-and-stick approach matches the theory developed in the political science literature on state accommodation versus repression. The government tends to be tough and impose sanctions if its controlling position is challenged (e.g., Acemoglu and Robinson (2000a); Davenport (2007a, 2007b); Walter (2006)). The 2008 Tibet and 2009 Urumqi riots triggered punishment from government shareholders, punishment that was intended to deter future demands for greater autonomy in those regions. Resource deployment in privately owned business groups, however, is insensitive to adverse social shocks.

Secondly, regarding labor markets and firm investments, my results suggest that the injection (withdrawal) of funds is associated with increases (decreases) in labor payments, number of employees, and capital expenditure. As is shown by Besley and Persson (2011), increasing labor payments and investment levels is an important means of preventing conflicts from breaking out. The economic effect is sizable. Moving from the bottom to the top decile in the distribution of additional funds received around the time of shocks is associated with $17 \%$ higher labor payments, 3\% more employees, and 18\% greater capital expenditure in SOEs located in affected cities. However, no significant changes are found in non-SOEs.

Third, by addressing social unrest, SOEs' incentives deviate from shareholder value maximization, and accordingly, shareholders of SOEs experience losses in market value relative to book value. Moving from the bottom to the top decile in the distribution of additional funds received around the time of shocks is associated with $11 \%$ higher book-to-market ratio in SOEs located in affected cities, which indicates that SOEs' market values decrease relative to book 
values. In contrast, when it comes to value, non-SOEs are immune to these same shocks, presumably because non-SOEs lack incentives to respond with distortive resource allocations. Despite the damage to SOEs' values, additional results suggest SOEs' effort of maintaining stability may benefit local firms' performance in the relatively longer term.

Finally, to infer the impact on social sentiment of SOEs' activities, I relate the city-level sentiment index to the operations of SOEs in those cities. ${ }^{4}$ I find local sentiment deteriorates in cities that experience shocks. However, it recovers to pre-shock levels if SOEs respond to the shocks by carrying out more related party transactions aimed at such cities.

The paper contributes to four strands of literature. First, I add to the political economy literature on the interaction between governments and social unrest. To deal with social unrest, a state can either accommodate or repress, depending on which option yields higher net benefits (Acemoglu, Hassan, and Tahoun (2014); Acemoglu and Robinson (2000a, 2000b, 2001); Aidt and Franck (2015); Besley and Persson (2011); Davenport (2007a, 2007b); Walter (2006)). My paper contributes to this literature by documenting a novel channel whereby resource allocation within state-owned business groups can potentially be used by governments to neutralize social tension created by adverse shocks to stability.

Secondly, the findings in this study are closely related to a recent debate on firms' noneconomic goals (Bénabou and Tirole (2010); Hart and Zingales (2017); Hsu, Liang, and Matos (2017)). I document SOEs' non-economic goal of maintaining social stability and show that the benefits offered by SOEs to the public can help restore stability.

Thirdly, this paper contributes to studies on allocative strategies in business groups. The previous literature documents the ways in which business groups can strategically deploy resources through internal capital markets to achieve expropriation (Dyck and Zingales (2004); Cheung, Rau, and Stouraitis (2006, 2010); Jiang, Lee, and Yue (2010)), alleviation of financial constraints (Buchuk et al. (2014); Almeida, Kim, and Kim (2015)), or coinsurance (Jia, Shi, and Wang (2013); Ljungqvist et al. (2017)). Using transactional-level data, I show that the political goal of maintaining social stability is a driving force of resource allocation in business groups.

Lastly, my paper speaks to political intervention in economic activities such as government procurements during times of crisis (e.g., Goldman (2017)) and regional favoritism (e.g., Hodler

\footnotetext{
${ }^{4}$ The sentiment index starts in August 2009. Only incidents of social unrest that occurred after 2009 can be analyzed. The events that occurred after 2009 include all events that SOEs addressed by offering benefits to local residents.
} 
and Raschky (2014)). I show that governments intervene not only for economic reasons, but also for social ones. The time-varying shifts in resource allocation that I document are probably unlike the even spread of resources over time and across geographies implied by studies on regional favoritism. Overall, my paper provides new evidence on distortion in resource allocation in politically connected firms, and documents its social consequences (e.g., Bertrand et al. (2006); Faccio (2006); Fisman (2001); Khwaja and Mian (2005); Shleifer (1998); Shleifer and Vishny (1994)).

Section II of this paper develops testable hypotheses. Section III describes the institutional settings and introduces the shocks examined herein. Section IV provides the data, and Section V presents the empirical analysis and results. Section VI addresses robustness tests. My conclusions are presented in Section VII.

\section{Theoretical framework}

I develop a framework that predicts a government's response to episodes of social unrest. Government shareholders could, then, bring the strategy to SOEs and implement it as a guideline for resource management in restless times. When a government perceives a threat to social stability, it can either accommodate the threat by offering benefits or repress it by imposing sanctions. ${ }^{5}$ Before making the decision, the government weighs the costs and benefits of the two options. While it is difficult to discuss exhaustively all possible factors in the government's assessment, I try to focus on the nature of unrest events. This focus is supported by the literature described below.

In his review paper, Davenport (2007a) points out that the most vital aspect of social unrest that a government cares about is whether the unrest challenges its political power. When social unrest challenges the status quo, an authority generally employs some form of repressive action to counter or eliminate the threat. The net benefit of repression in this case is high because failing to resolve challenges to the authority's position results in its losing control.

When the threat to social cohesion is triggered by isolated incidents that do not directly challenge its political power, governments are reluctant to engage in repression, because the

\footnotetext{
${ }^{5}$ I do not separately discuss the two extreme options where (1) the government launches a civil war or (2) full democratization is adopted. In my framework, I merge the option of civil war into state repression because sanctions and civil war share common roots (Besley and Persson (2011)), and they both mean that the government has chosen to be tough. Focusing on regional unrest, I rule out the possibility of full democratization. Democratization is ultimately an extreme form of accommodation.
} 
benefit of such an approach is low. Davenport (2007b) looks into different types of autocracies and finds that democratic and single-party regimes are generally less repressive than other autocracies because the former two have more flexibility in promoting alternative mechanisms of socio-political control. Unlike democratic governments, which can allow individuals and groups to express their needs, single-party regimes can offer direct benefits to disaffected groups in order to offset social tensions. When the government imposes the above strategies on SOEs, I obtain the first set of hypotheses:

Hypothesis 1a: If a social unrest event does not challenge an authority's regional political power, government shareholders will transfer resources to business group units located in areas that experience adverse shocks to social stability (the "carrot").

Hypothesis 1b: If a social unrest event challenges an authority's regional political power, government shareholders will withdraw resources from business group units located in affected areas (the "stick").

Given the resource reallocation strategies above, one might wonder through which channels the additional resources can effectively offset social panic. Besley and Persson (2011) provide an answer: they find that higher labor payments and levels of investment reduce the likelihood of conflicts. Following this finding, it is expected that SOEs use additional resources to improve labor conditions and boost capital expenditure in order to offset social panic.

Hypothesis 2: Employment, labor payment and levels of firm investment in SOEs are positively correlated with the net cash inflow received by SOEs in affected cities around shocks.

Financial economists care about the efficiency of resource allocation within firms because it ultimately affects firms' value. The political objective of maintaining social stability deviates from the neoclassical efficiency of maximizing shareholders' value because it requires resources to flow into areas that are experiencing unrest and generate benefits to the local residents rather than going to profitable projects. In this end, inefficient resource deployment rises within firms, which results in the destruction of shareholder value.

Hypothesis 3: The political objective of maintaining social stability in SOEs results in the destruction of shareholder value. 
Adverse shocks to social stability are capable of generating tension in society. When local people experience such shocks (e.g., terrorist attacks), they can become worried. The spillover effects of the shocks can damage local sentiment. However, the benefits offered by SOEs to the local residents might offset the tension and restore peace. Therefore, I hypothesize:

Hypothesis 4: Local sentiment deteriorates in cities that experience adverse changes to stability. The presence or the response of SOEs to the events helps restore the level of sentiment.

\section{Institutional background}

\section{A. Chinese business groups and related-party transactions}

Business groups play a major role in the Chinese economy. A typical business group in China comprises the holding company, listed firm(s) held by the controller, and many other (predominantly non-listed) subsidiaries, controlled either by the controller or by the listed firm(s). Based on the nature of ultimate controllers, Ljungqvist et al. (2017) identify in total 211 government-owned business groups and 76 privately owned groups over the period 2004-2013. While it is difficult to estimate the total size of state-owned and non-state-owned business groups, among all A share listed firms, SOEs and non-SOEs account for $42 \%$ and $58 \%$, respectively, of the total market value (2014) and both of them are spread across mainland China.

The Chinese stock markets mandate the disclosure of related party transactions (RPTs), which are deals conducted within the same business groups. Figure 1 depicts a typical business group structure and RPTs. RPTs, as shown in the figure, enable resource allocation in the internal capital market of business groups. The details of the RPTs' data are introduced in part IV.

\section{B. Social stability and regional shocks}

The Chinese government emphasizes the importance of social stability in the pursuit of economic development. The concept of a "harmonious society" was brought up in 2004, in the 16th Central Committee of the Communist Party of China (CPC), and the office of the central

leading group for maintaining stability (中央维护稳定工作领导小组办公室) was set up one year later. Since then, maintaining stability has become a central goal of the Chinese government (Geis, John, and Holt (2009)). The emergence of the "harmonious society" concept lays out an accommodating attitude in handling social unrest. According to the guidelines, building a 
"harmonious society" is a continuing process of resolving social conflicts and nipping them in the bud. Vulnerable groups should be supported and guaranteed that they will be able to benefit from social and economic development. ${ }^{6,7}$ SOEs are active agents in this process. The Chinese SOEs are believed to be shock absorbers in the economy. For example, SOEs could be required by the government to reserve vacancies to absorb unemployed individuals. ${ }^{8}$ However, despite the policies, the number of episodes of social unrest has increased substantially in the last two decades in China. According to Tanner (2014), various forms of protests grow from 8,700 in 1993 to 60,000 in 2003 and more than 120,000 by 2008 as reported. The total spending on domestic security reached 514 billion Chinese yuan (roughly US\$76.7 billion) in 2009, which is comparable to the military budget of 530 billion Chinese yuan. ${ }^{9}$ The spending outgrew the military budget in subsequent years. ${ }^{10}$ With the exception of subsidies of vulnerable groups, this spending reflects the build-up of domestic security forces such as police and surveillance facilities.

Even though almost no incident has affected stability on the national level, China does not lack for incidents that disturb social stability regionally. Regional incidents, by generating pressure on local stability, contribute to identifying the causal inference from social instability to resource deployment in SOEs. I collect salient events for the tests from the survey "Conflict Barometer," compiled by the Heidelberg Institute for International Conflict Research, an annual survey that reports conflicts globally. For each country, the report creates a set of topics describing all the relevant conflicts in the country, and then tracks all the specific events that happen each year by category. Categories are rated each year according to severity, from 1 (lowest) to 5 (highest). I focus on the highest-rated categories, which include territorial disputes, social-economy conflicts, and ethnic conflict in China. ${ }^{11}$

\footnotetext{
${ }^{6}$ J. Wang, “Build a harmonious society: Keep resolving social conflicts” (构建和谐社会 : 不断化解社会矛盾的过 程), People, October 12, 2006.

${ }^{7}$ S. Feng, "Building a harmonious society requires solving problems among vulnerable groups" (构建和谐社会必 须解决弱势群体问题), People, July 21, 2005.

${ }^{8}$ Y. Zheng, "Shocks and absorbers," The Economist, January 16, 2016.

${ }^{9}$ C. Buckley, "Analysis: China price for stability raises alarm," Reuters, October 14, 2010.

${ }^{10}$ B. Blanchard and J. Ruwitch, "China hikes defense budget, to spend more on internal security," Reuters, March 5, 2013.

${ }^{11}$ Regarding conflicts involving China since 2008, the highest-rated conflicts are, for ethnic conflicts, Tibet-Han and Uighur-Han (rated between 3 and 4); for territorial conflicts, the Senkaku/Diaoyu Island disputes (rated 2); and socioeconomic conflicts (rated between 3 and 4 ).
} 
In the end, I include eight events between 2008 and 2014. The events are: (1) Japanese and Chinese boats collided near the Senkaku/Diaoyu Islands in September 2010; (2) Tibetan students protested education reform in October 2010, Qinghai province; (3) The Japanese government's nationalization of the Senkaku/Diaoyu Islands in September 2012; (4) The Bo Xilai incident in March 2012, Chongqing; (5) A car bomb in Tian'anmen Square in October 2013, Beijing; (6) Muslim extremist groups randomly attacked civilians in Kunming, Guangzhou, Changsha, and Huaihua in March 2014; (7) The Tibet riot in March 2008; and (8) The Urumqi riot in July 2009. Table 1 gives an overview of dates, affected areas, a brief description, and media coverage of all these incidents. By selection, the eight events represent most severe social unrest episodes during the sample years, which might not be representative for unrest episodes with lower severity in China. In robustness test, I relax the selection criteria by including less severe events, and discuss the results accordingly.

These eight events can be ex ante classified as either "carrot" events, which the government tries to resolve by offering benefits to groups at risk; or "stick" events, which the government represses. The 2008 Tibet and 2009 Urumqi riots are potential "stick" events. Riots due to a desire for ethnic separatism represent an extreme category of political conflicts and are the type of social unrest most likely to trigger state sanctions. By demanding high-level autonomy or total independence, such riots put the local rule of the CPC at risk. According to hypothesis $1 \mathrm{~b}$, government shareholders are more likely to apply the "stick" in cases such as the Tibetan and the Urumqi riots. In addition, several characteristics further prevent government accommodation in the two riot cases. First, Tibetans and Uighurs are very different from the majority Han Chinese in terms of culture, such as language, religion, and lifestyle, which undermines mutual trust (Avruch (1998)). Secondly, government tends to create a reputation of toughness for itself when faced with more than one separatist group (Walter (2006)). The purpose is to set a harsh example for other groups and deter future incidents. Thirdly, the two autonomous regions receive constant subsidies from the government. For example, Wei (2015) calculates the accumulated subsidies to Tibet from 1952 to 2013 as 542 billion Chinese yuan, accounting for over $90 \%$ of Tibet's financial revenues. For Xinjiang, it is reported that the central government planned to provide support in the amount of more than 25 billion Chinese 
yuan after 2010. ${ }^{12}$ Moore (2000) shows that government adopts tactics of repression when earlier accommodations are met with dissent, and of accommodation when they are accepted. In other words, government will withdraw regular subsidies to a target group when subsidies fail to prevent unrest. The remaining six events are more likely to be "carrot" events, either because they disturb local stability but do not challenge the rule of the authority, or because local stability is affected by either external forces (e.g., foreign countries and terrorists) or government failures (scandals involving politicians and the failure of local policies). In Session V, I conduct separated tests for the six "carrot" events jointly and the two "stick" events jointly.

Despite the ex ante classification according to the prediction of political science literature, I also take an agnostic approach to let data reveal how the government addresses each of the included unrest events by testing them individually in Session VI.

\section{Data}

I build my analysis on four main sources: (1) data on related-party transactions; (2) firm ultimate controller information; (3) labor and financial data; and (4) a local sentiment index.

\section{A. Related party transactions}

Data on related party transactions of Chinese listed firms is available in the CSMAR Related Party Transactions research database. CSMAR includes data on approximately 500,000 deals from 1997 to the second quarter of 2015. A related party is defined as related according to one of twelve categories: between a firm and its (1) holding company, (2) subsidiaries, (3) commonly held firms, (4) major investors, (5) joint venture/associated firms, and (6) key managers, as well as six others. ${ }^{13}$ I only include deals conducted between entities that have common shareholding. The data cover various aspects of business between firms. I focus on six types of transactions: (1) commodities, (2) assets, (3) intra-debt, (4) guarantees, (5) equity transactions, and (6) direct transfer free of charge. ${ }^{14}$ The data allows me to extract information about the transaction date, products, and/or services exchanged; the amount of the transaction; and pricing rules. Owing to a lack of financial and investment data regarding non-listed firms, I only include deals involving

\footnotetext{
${ }^{12}$ Y. Wang and J. Yang, “An update on the support to Xinjiang economy” (支援新疆经济发展政策全面维新), Caijing, May 14, 2010.

${ }^{13}$ The CSMAR database defined 12 different categories for related parties. For conciseness, I merged them into 7 categories.

${ }^{14}$ The CSMAR database offers a total of 21 different categories of transactions. The six categories in my sample account for $80 \%$ of all the deals.
} 
listed firms. ${ }^{15}$ I start with the year 2007 for the data quality of related party transactions. This screening strategy leaves me with 244,723 deals from 2,551 firms. The average size of transaction in terms of Chinese yuan is 123 million-roughly US\$18 million. Table 2, panel A, reports the summary statistics of related party transactions.

\section{B. Controlling shareholders}

Data on the controlling shareholders of listed firms is obtained from the RESSET database. The dataset classifies eight different controlling shareholder types, which enables me to classify firms into central-government-owned enterprises, local-government-owned enterprises, and all the other non-state-owned enterprises. ${ }^{16}$ I have 762 SOEs accounting for $30 \%$ of firms in my sample.

\section{Labor, investment, and financials}

From CSMAR, I collect firms' quarterly total labor payment, capital expenditure, and number of employees. All the quarterly firm financial data is from CSMAR too, such as firm equity, leverage ratio, cash-to-assets ratio, and return on assets. Summary statistics for both labor and financial data are reported in Table 2, panel B.

\section{Local sentiment}

To construct the local sentiment index, I use the Weibo Social Moods data compiled by Chen et al. (2015). Weibo is a Chinese social-media platform similar to Twitter. Because Weibo is the major social media platform in China, the content of its posts could be a reflection of local sentiment. ${ }^{17}$ To construct the dataset, a random number of posts are scraped daily. In total, the dataset contains 1 billion posts from August 2009 to November 2014. Each post can be traced to the city from which it originates by tracking users' IP addresses. The content of the posts is then compared to keywords indicating six emotions: Happiness, Anger, Sadness, Disgust, Fear, and Surprise. Each emotion has a list of keywords identified by the authors. There are in total 306 keywords for Happiness, 93 keywords for Anger, 205 keywords for Sadness, 142 keywords for Disgust, 72 keywords for Fear, and 27 keywords for Surprise. When a post has a match with one

\footnotetext{
${ }^{15}$ While I am collecting non-listed firms information, listed SOEs account for significant share of the overall state owned economy. At province level, listed SOEs account for on average $60 \%$ of the total assets during the sample year. In addition, listed firms receive substantially more attention from the investors. If the goal were to maintain stability through SOEs, government would make its effort as visible as possible by working through listed SOEs.

16 The eight categories are (1) central-government-owned firms, (2) local-government-owned firms, (3) private firms, (4) collective firms, (5) university-affiliated firms, (6) foreign-owned firms, (7) trade-union-owned firms, and (8) other.

${ }^{17}$ Bollen, Mao, and Zeng (2011) argue that the tweets submitted to Twitter at any given time may provide an accurate representation of public sentiment, and they find the predictions of the Dow Jones industrial average can be significantly improved by including Twitter-based sentiment.
} 
of the above keywords, it is scored 1 point for the corresponding emotion. The data thus provides me with daily emotion scores calculated using a given day's sampled posts across 500 cities and/or regions around the world. In my test, I focus only on 107 Chinese cities that can be matched to firms' data. The data allows me to construct the sentiment index at a city level and at a high (quarterly) frequency. It is important to obtain a timely measure of local sentiment in my study, because low-frequency (e.g., annual) measures cannot capture the immediate change of sentiment around social unrest events.

\section{Empirical analysis and results}

In this part, I test the carrot-and-stick hypothesis of resource allocation in state-owned business groups. First, I examine the direction and magnitude of resource allocation within business groups. I always separate the firms sampled into SOEs and non-SOEs. Secondly, I look into the implications of the allocation strategy for the labor market, the firm's investment level, and its valuation. Finally, I associate local sentiment with the presence and activities of SOEs.

\section{A. Resource allocation upon adverse shocks}

Resource assignment within business groups is revealed by the related party transactions. I define two measures to capture (1) the volume of transactions in monetary terms and (2) the intensity of price distortion. To measure the volume of transactions, I construct net inflow, which is the net cash inflow to a firm generated by related party transactions. In each deal, a firm is either a seller or a buyer and is expected to receive or pay out a certain amount of money. I aggregate the amount of net inflow at the quarterly level for each firm. A positive net inflow, then, means that a firm receives funds on average during the quarter, and vice versa. Net inflow is scaled by the firm's total assets in the same quarter. To measure the price distortion in transactions, I define the ratio of political deals, which is the ratio of the net number of deals conducted following off-market prices that bring in cash to the total number of deals that occurred in a given quarter. The data provides an indicator variable and classifies pricing rules into thirteen categories, which enables me to differentiate whether deals follow market prices or not. ${ }^{18} \mathrm{I}$ define deals that follow market prices as "market deals" (category 1) and all the

\footnotetext{
18 The 13 categories are (1) market price, (2) conditional market price, (3) agreed-upon price, (4) nationally regulated price, (5) conditional nationally regulated price, (6) local-government-regulated price, (7) bank interestrate-based price, (8) ex-factory price, (9) cost-based price, (10) tender price, (11) evaluated price, (12) face-valuebased price, and (13) other.
} 
remaining deals as "political deals". Deals that do not follow market prices potentially benefit the recipients or expropriate them. The percentage of net off-market-priced deals in a given quarter, therefore, measures the intensity of price distortion in resource allocation. With this measure, I can show that even if the total amount of funds transferred does not change around a shock, the level of price distortion may increase. The summary statistics of both scaled net inflow and ratio of political deals are presented in Table 2, panel B.

With respect to shocks to regional social stability, I try to identify that resource allocation within state-owned business groups is driven by the political goal of maintaining stability. The regression follows a difference-in-differences approach. The specification is:

$$
\frac{\text { Net inflow }_{f q}}{\text { Total assets }_{f q}}=\alpha_{f}+\alpha_{q}+\alpha_{\text {area }, q o y}+\beta \text { Post }_{q} \times \text { City }_{f}+\gamma^{\prime} x_{f q}+\varepsilon_{f q}
$$

The dependent variable is the ratio of Net inflow to Total assets of firm $f$ in quarter $q$. I regress the variable on an indicator, Post, equal to 1 in four quarters, subsequent to each shock listed in Table 1; another indicator, City $_{f}$, equal to 1 if a firm is located in a city that experiences social unrest events; and the interaction term Post $_{q} \times$ City $_{f}$. The term $x$ is a vector of firm and macroeconomic control variables, including the natural logarithm of firm equity, return on assets, leverage ratio, cash-to-asset ratio, the natural logarithms of local GDP, population, and fiscal expenses. The cities treated in each event are listed in Table 1, in the "affected area" column. Firm fixed effects, quarter fixed effects, and economic zone-quarter of the year fixed effects are included, and therefore only the coefficient of the interaction term is identified. Government policy makers designed the concept of economic zones with the aim of smoothing the promotion of the collective economy and cooperation between provinces. Controlling economic zonequarter of the year fixed effects, therefore, helps to absorb confounding effects from the business cycle. Using the broadest definition of economic zone, China is divided into four zones. A positive $\beta$ coefficient in equation (1) indicates the "carrot", approach where firms located in affected cities receive additional funds. Otherwise, a negative $\beta$ coefficient indicates the "stick" approach. Standard errors are double-clustered at the city and quarter level.

In practice, I conduct tests by merging multiple events together and generate a continuous treated variable Treated $_{c q}$ that equals 1 in the following 4 quarters in cities after unrest breaks out, otherwise 0. Equation (1), therefore, is transformed into (1') below:

$$
\frac{\text { Net inflow }_{f q}}{\text { Total assets }_{f q}}=\alpha_{f}+\alpha_{q}+\alpha_{\text {area,qoy }}+\beta \text { Treated }_{f q}+\gamma^{\prime} x_{f q}+\varepsilon_{f q}
$$


I use equation (1') to test the groups of "carrot" and "stick" events separately.

In order to examine the change in the level of price distortion around each, I alternatively replace the dependent variable in (1') with the Ratio of political deals: Ratio of political deals $f q=\alpha_{f}+\alpha_{q}+\alpha_{\text {area }, q o y}+\beta$ Treated $_{f q}+\gamma^{\prime} x_{f q}+\varepsilon_{f q}$

A positive $\beta$ coefficient in equation (2) implies that firms located in affected cities engage in more distorted transactions, while a negative $\beta$ suggests a lower price distortion in transactions.

Estimates of (1') and (2) are reported in panels A and B of Table 3, respectively. Columns (1)-(2) present results for "carrot" events; columns (3)-(4) present results for "stick" events. According to hypothesis 1a, for "carrot" events I expect to observe that government shareholders inject funds into SOEs located in affected areas, and that the level of distortion in deals increases after shocks. Indeed, the results in column (1) in both panel A and panel B confirm my hypothesis. SOEs located in areas of unrest receive on average 0.9 percentage point more net cash inflow relative to firm assets, which is $14 \%$ of one standard deviation (6.6) more than SOEs located in areas not affected by unrest. This amount corresponds to 543 million Chinese yuan $(0.9 \% \times 15.1$ billion $\times 4)$, roughly US\$84 million, in the year following the shocks. The total dollar value transferred through related party transactions accounts for $2 \%$ of the total average fiscal expenditure of Chinese cities in 2011. Regarding price distortion, the ratio of net political deals to total number of deals increases by 7.3 percentage points, or $13 \%$ of one standard deviation more for SOEs in affected areas. Results for "stick" events focus on the March 14, 2008 Tibet riot and the July 5, 2009 Urumqi riot. The hypothesis predicts that government shareholders punish defiance and deter future rioting by withdrawing funds after a riot. The results in column (3) confirm hypothesis $1 \mathrm{~b}$. I find a significant drop in the net cash inflow and in the level of price distortion among transactions involving SOEs located in Tibet, Aba, and Urumqi. However, at a smaller magnitude, the coefficient suggests that the riots led to a decrease of 0.5 percentage point ( $8 \%$ of one standard deviation) in the ratio of net cash inflow to firm assets, and a decrease of 8 percentage points ( $16 \%$ of one standard deviation) in the ratio of political deals. The outflow of funds was on average US\$22 million per SOE in the year after each riot. This suggests that the government reduces the level of subsidies to Tibet and Xinjiang economies after riots. 
Regarding non-SOEs, I conduct the same analysis; the results are reported in columns (2) and (4). I expect resource allocation in non-SOEs to be insensitive to social unrest. The primary goal of non-SOEs is to generate value for their owners. On the one hand, without government shareholders, non-SOEs lack any incentive to comply with a given political objective. On the other hand, even if the business environment becomes unstable, non-SOEs would not necessarily take away from the affected areas because they anticipate that the government (shareholders) would respond to incidents of social unrest. The cost of relocation could be too high to be a viable option. Throughout, the estimated coefficients are statistically insignificant. To the extent that I do not find resource allocation in non-SOEs to change significantly with respect to shocks, the results are in line with my expectations.

In addition, I explore two potential heterogeneous effects between different types of SOEs. Ljungqvist et al. (2017) show that CEOs in SOEs tend to comply with government's political goals because of promotion incentives. The finding implies that local-government-owned SOEs might react to local social unrest more strongly than central-government-owned SOEs. To test this cross-sectional variation within SOEs, I interact the variable Treated $_{f q}$ with a dummy variable, Central , equal to 1 if a firm is owned by the central government, and 0 otherwise. The estimates are reported in Table B.1 columns (1) and (3). Throughout, the coefficients on the interaction term are statistically insignificant. The result implies that central-government-owned SOEs respond to adverse events as strongly as do local-government-owned SOEs. Another expectation is that firms in sectors owned by the government with less external competition could display stronger effects in responding to social unrest events. Due to the lack of competition, firms in these sectors could cater more to the political pursuit of the government. To test it empirically, I classify SOEs into so-called state monopoly industries and non-state monopoly industries according to $\mathrm{Du}$ (2010) and Chen (2008), which identify 13 sectors as Chinese state monopoly sectors. ${ }^{19}$ The results are reported in columns (2) and (4) in Table B.1, I find no statistically significant coefficients on the interaction term, suggesting the difference

\footnotetext{
${ }^{19}$ The state monopoly sectors include 1) oil and gas exploration, 2) tobacco, 3) petroleum processing, 4) coking and nuclear fuel processing, 5) electricity, heat production and supply, 6) gas production and supply, 7) water production and supply, 8) railway transport, 9) postal service, 10) telecommunications and other information transmission services, 11) financial services, 12) non-ferrous metals exploration and processing, and 13) ferrous metal exploration and processing.
} 
between state monopoly sectors and non-monopoly sectors in terms of addressing social unrest events is insignificant.

In shock-based studies, it is crucial to show that a parallel trend assumption holds between treated and controlled firms (Atanasov and Black (2016)). A parallel trend indicates that (1) results are not contaminated by any pre-treatment shocks to either firms that are treated or control firms; and (2) the treatment is not anticipated before it happens. I provide empirical support by showing that resource allocation in SOEs located in affected areas only starts to change after a shock. I plot the point estimates from a modified version of equations ( $\left.1^{\prime}\right)$ and (2), where I introduce the cohort dimension to create control groups for each individual event and

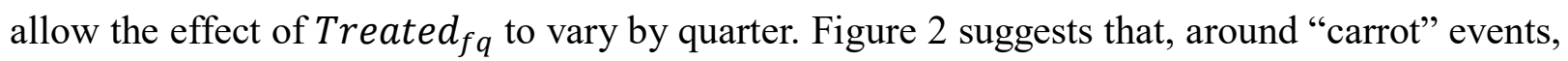
the increase in net cash inflow (graph on left) and the level of price distortion (graph on right) are significant only after the normalized event dates.

In sum, this section presents the carrot-and-stick strategy in SOEs' decisions to allocate resources with the aim of maintaining social stability. Depending on the nature of the shock, funds are injected into or taken away from SOEs in affected areas. The level of price distortion also changes around the shocks. A natural question would be: does the allocation plan have real effects on the labor market and on the firm's investment decisions?

\section{B. Labor market and firm investment decisions associated with resource allocation}

Hypothesis 2 states that SOEs, upon receiving (the withdrawal of) resources, increase (decrease) various benefits to employees or local residents with the purpose of neutralizing the negative effect of the shock. In practice, firms can generate or reduce benefits to the public by altering their policies in the labor market and in investment decisions. I therefore relate (1) labor payments, (2) hiring decisions (the number of employees), and (3) investment levels (capital expenditure) to the changes in funds received by SOEs around shocks. In this test, I merge both "carrot" and "stick" events together. As SOEs' policies hinge only on whether they obtain additional resources around shocks, there is no need to differentiate between "carrot" and "stick" cases. The equation is specified as:

Firm policy $_{f q}=$

$$
\alpha_{f}+\alpha_{q}+\alpha_{\text {area,qoy }}+\beta_{0} \text { Treated }_{f q} \times \Delta \text { Cash }_{f}+\beta_{1} \text { Treated }_{f q}+\gamma^{\prime} x_{f q}+\varepsilon_{f q}
$$

On the right-hand side, the variable Treated $_{f q}$ interacts with $\Delta \operatorname{Cash}_{f}$, which is the change in funds received by firm $f$ around a shock. As shown in equation (4), I compute it by taking the 
first difference of the medians of the net cash inflow to total assets ratio in firm $f$ in shock- and non-shock periods.

$$
\Delta \operatorname{Cash}_{f}=\operatorname{Median}\left(\frac{\text { Net inflow }_{f q}}{\text { Total assets }_{f q}}, \text { Post }_{q}=1\right)-\operatorname{Median}\left(\frac{\text { Netinflow }_{f q}}{\text { Total assets }_{f q}}, \text { Post }_{q}=0\right) \text { (4) }
$$

A positive $\Delta \operatorname{Cash}_{f}$, therefore, means firm $f$ receives more funds after a shock. In the regression, firm fixed effects, quarter fixed effects, and economic zone-quarter of the year fixed effects are included. A positive and statistically significant $\beta_{0}$ is expected for SOEs, while firm policies in non-SOEs should be insensitive to events that threaten social cohesion.

Estimates of (3) are reported in Table 4 for SOEs (odd-numbered columns) and non-SOEs (even-numbered columns). The coefficients on the interaction term in columns (1), (3), and (5) are positive and statistically significant. The results indicate that moving from the bottom to the top decile in the distribution of additional funds (1.06) received around the time of a shock is associated with $17 \%(1.06 \times 0.04 \times 4)$ higher labor payments, $3 \%(1.06 \times 0.007 \times 4)$ more employees, and $18 \%(1.06 \times 0.045 \times 4)$ higher capital expenditure in an SOE located in an affected city in the year following a shock.

Results of the interaction term for non-SOEs are presented in columns (2), (4), and (6), and throughout, coefficients are not statistically different from 0 . It confirms that resource allocation and various firm policies in non-SOEs do not aim to address social issues.

To sum up, my finding consistently supports the prediction that SOEs use the funds received around a shock to generate benefits to employees or local residents. Specifically, SOEs increase payments for labor, capital expenditure, and the number of employees.

\section{Valuation implication for firms}

In this section, I study the valuation implication when SOEs meet the political goal of maintaining social stability. It is costly to shareholders if a firm's incentive deviates from value maximization toward the political goal. Inefficiency arises because scarce resources, rather than being deployed at the best investment opportunities, flow now to regions of unrest. To show the value implication of the carrot-and-stick strategy around a shock, I follow equation (3) and replace the dependent variable with a firm's book-to-market ratio.

I estimate the equation for SOEs and non-SOEs, respectively, and the results are presented in Table 5. In column (1), the coefficient on the interaction term Treated $_{f q} \times \Delta$ cash $_{f}$ is positive and statistically significant for SOEs. Moving from the bottom to the top decile in the 
distribution of additional funds received around the time of a shock is associated with 11\% (1.06 $\times 0.03 \times 4 / 1.1)$ higher book-to-market ratio in SOEs located in affected cities, indicating lower market-to-book values. Investors indeed perceive the injection of funds into affected areas as a source of inefficiency. They are able to form this belief and trade on it because listed firms are required by regulators to disclose related party transactions. In contrast, the coefficient on the interaction term in column (2) for non-SOEs is negative and statistically insignificant. Shareholder value for non-SOEs seems to be insulated from shocks to regional social stability and any resource allocation around them.

Overall, the results confirm hypothesis 3, along with the finding in the political connection literature that political incentives can distort resource allocation within firms, resulting in inefficiency. Given the value destruction of the carrot-and-stick strategy in SOEs, the more important question is: does a strategy that aims to maintain social stability generate positive externalities?

\section{Local sentiment and firm action}

In my study, it is important to document empirically that the benefits offered by SOEs indeed help to offset social tension caused by various kinds of shocks. To capture local sentiment across Chinese cities and measure it at the quarterly frequency, I use the "Weibo Social Moods" dataset (Chen et al. (2015)). Since the dataset ranges from August 2009 to November 2014, it allows me to conduct analysis only on "carrot" events for the coverage of both pre- and postshock periods. I take the keyword score of "happiness" as a measure of positive sentiment. I normalize keyword scores of positive sentiments by the number of corresponding keywords used to generate the scores and the number of total posts sampled in a given quarter. The index can be expressed by the following formula:

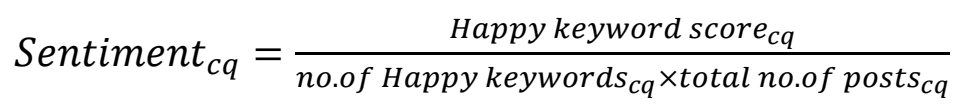

As the test can only be conducted at the city level, I need an aggregated measure of SOE and non-SOE activities in each city. I first consider whether a city has listed SOEs or not (SOE (Y/ $N)$ ). I expect sentiment to improve more in cities where listed SOEs operate compared to other treated cities that have no listed SOEs at all. The implicit assumption is that SOEs would always implement the carrot-and-stick strategy in resource allocation. Second, more directly, I measure the relative size of related party transactions conducted by SOEs and non-SOEs in a city. To do so, I take the median of net cash inflow to total assets ratio for SOEs and non-SOEs, respectively, 
at the quarter and city levels. I then compute the ratio (SOE RPTS) between the two medians. A higher SOE RPTS means SOEs conduct more RPTs in a given city-quarter. I again use the first difference between the median of SOE RPTS at the city level to gauge the change in SOEs' activities around a shock. I expect greater improvement of local sentiment in cities where SOEs conduct more RPTs around a shock.

The regression equation is specified as:

Sentiment $_{c q}=$

$\alpha_{c}+\alpha_{q}+\alpha_{\text {area,qoy }}+\beta_{0}$ Treated $_{c q} \times S O E_{c q}+\beta_{1}$ Treated $_{c q}+\beta_{2} S O E_{c q}+\gamma^{\prime} x_{c q}+\varepsilon_{c q}(6)$

$S O E_{c q}$ is either of the above two measures, SOE $(Y / N)$ or $\triangle S O E R P T S$. I control for the same set of macroeconomic variables, namely, local population, fiscal expenditures, and GDP. Instead of including firm fixed effects, I control city fixed effects in this city-level analysis. Table 6 presents the results. Focusing first on columns (1) and (2), the coefficients on the interaction term Treated $_{c q} \times S O E(Y / N)_{c q}$ are positive and statistically significant, while coefficients on the variable Treated $_{c q}$ are negative and significant. The combination indicates that social unrest events damage sentiment in the treated cities. However, the presence of listed SOEs in such cities alleviates social tension. In terms of economic magnitude, the level of happiness decreases by $17 \%$ in cities where social unrest events occur, but conditional on listed SOEs exist in such cities, the level of happiness bounces back by 19\%. The results shown in columns (3) and (4) lend further support to the finding: cities where SOEs conduct more RPTs around a shock experience an improvement in sentiment. The results confirm hypothesis 4. The benefits generated by SOEs are positively associated with local sentiment. The more benefits SOEs offer, the more positive sentiment is reflected on social media. It suggests that the strategy adopted by government shareholders works for relieving tension caused by adverse events.

In addition, the change in the sentiment could be revealed slowly on social media. I, therefore, replicate the test using one-quarter forward sentiment, and controlling for the contemporaneous sentiment. Results are reported in columns (5) and (6). Coefficients are slightly bigger, indicating that the variation in sentiment is captured better with forward sentiment. It does seem to take time for the change of sentiment to reveal.

Another potential concern is that Weibo users might choose to express their true emotion only when they use virtual private network (VPN) due to government online censorship. This 
concern can be alleviated by two reasons: 1) I use the emotion "happiness", which is positive, as my sentiment measure. Compared to expressing negative emotion, it is less likely that Weibo users express happiness only with VPN. 2) The usage of VPN on Weibo seems to be limited. VPN enables Weibo users to disguise themselves with non-Chinese IP addresses, and these users will be located as "overseas". The number of overseas posts only accounts for less than 5\% of the total number of posts in the "Weibo Social Mood" dataset. Considering the 5\% of posts also include posts from actual overseas users, the precise number of VPN users is likely to be even smaller.

\section{Additional Tests}

\section{A. Reverse causality}

In this section, I address the issue of reverse causality: knowing that government shareholders would offer benefits to maintain stability, one could threaten to create trouble and ensure that such benefits would be forthcoming. This possibility undermines the exogeneity of various events. I address the issue by testing to find whether current benefits predict future conflicts. Specifically, I conduct analysis at the city level following the procedure described in section V.D (analysis of local sentiment). The goal is to find out whether conflicts happen more often in cities where listed SOEs are located, or whether listed SOEs conduct more RPTs around a shock. I combine both labor conflicts and terrorist attacks as a proxy for overall conflict incidents in China. I obtain the number of labor conflicts at the city level from the China Labor BulletinStrick Map, a database that has collected data on labor conflicts in Chinese cities since January 2011. I obtain data on city-level terrorist attacks from the Global Terrorism Database. The earliest terrorist attack recorded was in 2005. For the sake of consistency, I set the start of the merged dataset as January 2011. I use all the cases, including unconfirmed events (rumors), which can be mapped into a certain city. I focus solely on labor conflicts and terrorist attacks because these two types of events in China are surveyed systematically. Ideally, of course, I would like to obtain a more comprehensive measure of conflict. The regression follows equation (6), but the dependent variable becomes the number of conflicts at (1) the current time, (2) one quarter later, and (3) two quarters later. Table B.2 reports the estimates. Throughout, the coefficients on the interaction terms are statistically insignificant, indicating that neither the 
presence of SOEs nor the RPTs conducted by SOEs predict future conflicts. The results alleviate the concerns about revers causality in my tests. ${ }^{20}$

\section{B. Individual events}

In the main test, I classify the eight events ex ante into "carrot" events and "stick" events. Even though the prediction closely follows conclusion from the political science literature, the application could be questioned in the Chinese context. To lend support to the ex ante clarification, I test how SOEs respond to the eight social unrest events individually. In this approach, I let data reveal government shareholders' strategies. The results are reported in Table B.3 in the appendix. All the signs of the coefficients are in line with expectation. Namely, all tests on individual "carrot" events obtain positive coefficients, and tests on individual "stick" events obtain negative ones.

\section{Alternative channels}

Conflict resolution is a topic that concerns political, economics, and legal studies. To my best knowledge, there is no literature that reviews all potential channels that government can adopt to address social unrest across the three disciplines. I therefore first provide my incomplete summary, and then test one major direct channel. Finally, I discuss the relevance of the SOEs channel I am highlighting. Merging discussion in the political science and the economics studies, a government can accommodate and/or repress unrest events. Major forms of state accommodation include democratization (e.g. Acemoglu and Robinson (2000a)) which enables citizen to express their needs within the political system, and the provision of direct benefits, which could range from selective incentives, wages, bribes, fiscal redistribution to welfare systems (Davenport (2007b). In terms of state repression, mostly cited channels include both political and economic sanction, harassment, surveillance/spying, arrests, torture, and mass killing in the extreme (Davenport (2007a). The legal procedures to resolve conflicts and disputes are primarily negotiation, mediation, arbitration, and litigation. Compared to all the channels raised, the channel by which government uses SOEs to address social unrest events is an indirect one. However, as Davenport (2007a) mentions, the use of alternative channels by government to address conflicts is not examined extensively, and it is important to investigate because alternative channels could help maintain political order.

\footnotetext{
${ }^{20}$ Alternatively, I regress the number of conflicts directly on the median of an SOE's net cash inflow to the total assets ratio at the city level. The ratio is not predictive with respect to future conflicts.
} 
Despite my results suggesting the channel of SOEs is important and effective, I test one direct channel: fiscal redistribution around social unrest events. I focus only on this direct channel due to the lack of data on state surveillance/spying, harassment, or arrests, etc. Instead of using the network of government-owned business groups, the government could resolve threats to social stability by offering subsidies to everyone in affected cities directly through fiscal budgets. I show that the fiscal redistribution channel exists along the channel of strategic resource allocation in SOEs. I use the amount of "civil affair expenses" disclosed by the Chinese government at province and year level as a proxy for general social-welfare benefits provided by the government to the public regionally. Civil affair expenses are moneys spent by the government to guarantee civilians' basic welfare; it includes expenses for social welfare, a minimum living allowance, resettlement funds, etc.

I test the change of civil-affairs expenses relative to the GDP around shocks to social stability. The results are reported in Table B.4. The analysis is conducted at the province and year levels. I obtain positive coefficients. Based on the coefficient in column (3), the annual ratio of civil-affairs expenses to GDP increases $11.3 \%(0.096 / 0.85)$ in the provinces that experience shocks to social stability. The results indicate that the government employs multiple tools simultaneously to maintain social stability. Comparing the magnitude between the two channels, the results in Table B.4 suggest government transfer 241 million USD on average into affected provinces after shocks, while according to Table 3, one SOE transfers 84 million USD on average. The comparison shows that the SOEs channel is material.

\section{Firm performance}

Results in Session V.C show that SOEs incur immediate value destruction for addressing social unrest. However, it is not clear if maintaining social stability damages firm performance in the immediate future. On the one hand, shifting resources is costly for firms during social unrest, which could damage firm performance. However, on the other hand, stability allows firms to operate safely, and could contribute to future profits generation. Empirically, I replicate estimation in Session V.C, and replace the dependent variables as half-year or one-year forward return on assets (ROA). Results are reported in Table B.5. The positive and significant coefficient on the interaction term in columns (1) indicates that related party transactions conducted during social unrest is associated with increased profitability for the SOEs in two quarters after the shocks. However, the effect becomes insignificant one year later as results 
shown in column (3). For non-SOEs, results in column (2) and (4) show that non-SOEs in treated areas experience an increase in profitability two quarters and one year after the shocks, which does not depend on any related party transactions. It suggests non-SOEs may benefit from SOEs' increased investment. The results confirm, to some extent, that maintaining stability may benefit business growth.

\section{E. Price distortion}

In the test of price distortion in Table 3, an implicit assumption is that the prices in the political deals are distorted toward the benefits of the recipient SOEs. However, this may not be the case in practice. If prices are set in such a way that SOEs are overcharged, then the increase of political deals around shocks indicates not the injection of resources but their withdrawal. To address this concern, I focus on the percentage of guarantees deals provided to SOEs. By providing guarantees to the SOEs, the business groups offer collaterals and bear ultimate responsibility for repayment of the loans. SOEs could then potentially obtain loans that could not be obtained otherwise. The guarantees themselves are also severely mispriced and seem like free money. ${ }^{21}$ To some extent, the guarantees represent a form of distortion that is beneficial to the receivers. Therefore, I compute the ratio of the net number of guarantees received by the SOEs to the total number of deals in each quarter and test how it changes around shocks. The results are reported in Table B.6. The test follows exactly the specifications in Table 3, and I obtain results here that are very similar to those in Table 3. In particular, with respect to the subset of guarantees deals, the results suggest that distortion increases around "carrot" events and favors SOEs. Accordingly, distortion decreases around "stick" events and disadvantages SOEs.

\section{F. More events}

The eight social unrest events are more severe ones during the sample period. Consequently, results based on these events might not be applicable to unrest events with lower severity. To investigate government shareholders' respond to less severe unrest episodes, I replicate the test in Table 3 by including social unrest events with lower severity according to the survey. The

\footnotetext{
${ }^{21}$ J. Zhang, "Credit default swaps are storing up trouble for China," Financial Times, August 30, 2017.
} 
relaxation in selection criteria increases the number of "carrot" events from 6 to $25{ }^{22}$ The number of "stick" events remains the same. The results for "carrot" events are reported in Table B.7. The coefficients have the same signs and similar level of significance as those in Table 3. However, the economic magnitude reduces. On the one hand, the carrot-and-stick strategy is robust to including less severe unrest events. On the other hand, the reduced economic significance indicates that the government shareholders tend to use SOEs to address the most disturbing unrest episodes, possibly due to the large consumption of firm resources and the damage to firm values.

\section{Conclusion}

Relying on arguably unexpected shocks to regional stability, I find evidence that resource allocations within government-owned business groups respond to that threat of social stability at a cost of firm value. Government shareholders adopt a carrot-and-stick approach: On the one hand, the government gives a "carrot" by injecting funds into firms located in areas of unrest, funds that firms use to increase payments to employees, boost investment levels, and hire more employees. On the other hand, in cases of riots involving separatist movements, the government applies a "stick" by withdrawing funds. The switch in strategies matches theories from studies on state repression: political conflicts that challenge the rule of the incumbent government invite sanctions in various forms. It also matches the "reputation-building" hypothesis: governments tend to build a reputation of toughness when dealing with separatists, especially when there is more than one minority group involved. I also show that various benefits provided by government shareholders around shocks help to recover local sentiment. My paper provides new evidence that resource allocation in firms can deviate away from the neoclassical approach to fulfill political goals, and that SOEs can serve as a political governance tool for government to manage society.

\footnotetext{
${ }^{22}$ The 25 social unrest events include episodes with detailed information on the events and identifiable location with severity rated at 2 and above on the survey. Nevertheless, these events are still of high significance and visibility internationally. For the newly included events, there are 4 subnational predominance conflicts, 8 socioeconomic protests, 5 peasants protests, 1 religion/ideology conflict, and 1 territorial dispute.
} 


\section{References}

Acemoglu, D., T. Hassan, and A. Tahoun, 2014, The power of the street: Evidence from Egypt's Arab Spring, National Bureau of Economic Research.

Acemoglu, D., and J. Robinson, 2000a, Democratization or repression?, European Economic Review, 44(4), 683-693.

Acemoglu, D., and J. Robinson, 2000b, Why did the West extend the franchise? Democracy, inequality, and growth in historical perspective, Quarterly Journal of Economics 115, 11671199.

Acemoglu, D., and J. Robinson, 2001, A theory of political transitions, The American Economic Review, 938-963.

Aidt, T., and R. Franck, 2015, Democratization under the threat of revolution: Evidence from the great reform act of 1832, Econometrica 83(2), 505-547.

Alesina, A., and R. Perotti, 1996, Political instability, income distribution, and investment, European Economic Review 40, 1203-1228.

Almeida, H., C. Kim, and H. Kim, 2015, Internal capital markets in business groups: Evidence from the Asian financial crisis, The Journal of Finance, 70(6), 2539-2586.

Anderson, C.J., and C.A. Guillory, 1997, Political institutions and satisfaction with democracy: A cross-national analysis of consensus and majoritarian systems, American Political Science Review, 91(1), 66-81.

Atanasov, V., and B. Black, 2016, Shock-based causal inference in corporate finance and accounting research, Critical Finance Review, 5, 207-304.

Avruch, K., 1998, Culture and conflict resolution (Vol. 31), US Institute of Peace Press.

Bénabou, R., and J. Tirole, 2010, Individual and corporate social responsibility, Economica, 77(305), 1-19.

Berger, P., and R. Hann, 2007, Segment profitability and the proprietary and agency costs of disclosure, The Accounting Review, 82(4), 869-906.

Berger, P., and E. Ofek, 1995, Diversification's effect on firm value, Journal of Financial Economics, 37(1), 39-65.

Bertrand, M., F. Kramarz, A. Schoar, and D. Thesmar, 2006, Politicians, firms and the political business cycle: Evidence from France. Working paper.

Besley, T., and T. Persson, 2011, The logic of political violence. The Quarterly Journal of Economics, 126(3), 1411-1445.

Bollen, J., H. Mao, and X. Zeng, 2011, Twitter mood predicts the stock market. Journal of Computational Science, 2(1), 1-8.

Buchuk, D., B. Larrain, F. Muñoz, and F. Urzúa, 2014, The internal capital markets of business groups: Evidence from intra-group loans, Journal of Financial Economics, 112(2), 190-212.

Chen, G., 2008, Zhongguo qiye gaige fazhan sanshinian, Chinese Financial and Economic Publishing House.

Chen, H., Y. Dong, K. Lai, and L. Guo, 2015, Weibo social moods measurement and validation, Journal of Psychological Science, 38(5), 1141-1146.

Cheung, Y.-L., P. Rau, and A. Stouraitis, 2006, Tunneling, propping, and expropriation: Evidence from connected party transactions in Hong Kong, Journal of Financial Economics, 82(2), 343-386.

Cheung, Y.-L., P. Rau, and A. Stouraitis, 2010, Helping hand or grabbing hand? Central vs. local government shareholders in Chinese listed firms, Review of Finance 14(4), 669-694.

Davenport, C., 2007a, State repression and political order, Annual Review of Political Science 10, 1-23.

Davenport, C., 2007b, State repression and the tyrannical peace, Journal of Peace Research, 44(4), 485-504. 
Dewenter, K.L., and P.H. Malatesta, 2001, State-owned and privately owned firms: An empirical analysis of profitability, leverage, and labor intensity, The American Economic Review, 91(1), $320-334$.

Du, X., 2010, The earnings differentials between and within Chinese monopolistic sector and competitive sector: an empirical analysis on the basis of micro data in Beijing, Nankai Economic Studies, 5, 111-124.

Dyck, A., and L. Zingales, 2004, Private benefits of control: An international comparison, The Journal of Finance, 59(2), 537-600.

Faccio, M., 2006, Politically connected firms, The American Economic Review, 96(1), 369-386.

Fisman, R., 2001, Estimating the value of political connections, The American Economic Review, 91(4), 1095-1102.

Geis, I.I., P. John, and B. Holt, 2009, Harmonious society: Rise of the New China, Strategic Studies Quarterly 3, 75-94.

Goldman, J., 2017, Government as customer of last resort: The stabilizing effect of government purchases on firms, Working paper.

Hart, O., and L. Zingales, 2017, Companies should maximize shareholder welfare not market value (No. 12186), CEPR Discussion Papers.

Hodler, R., and P.A. Raschky, 2014, Regional favoritism, The Quarterly Journal of Economics, 129(2), 995-1033.

Hsu, P.H., H. Liang, and P.P. Matos, 2017, Leviathan Inc. and corporate environmental engagement, Working paper.

Hund, J., D. Monk, and S. Tice, 2012, Apples to apples: The economic benefit of corporate diversification, Working paper.

Jia, N., J. Shi, and Y. Wang, 2013, Coinsurance within business groups: Evidence from related party transactions in an emerging market, Management Science, 59(10), 2295-2313.

Jiang, G., C. Lee, and H. Yue, 2010, Tunneling through intercorporate loans: The China experience, Journal of Financial Economics, 98(1), 1-20.

Jones, C.I., and P.J. Klenow, 2016, Beyond GDP? Welfare across countries and time, The American Economic Review, 106(9), 2426-2457.

Khwaja, A.I., and A. Mian, 2005, Do lenders favor politically connected firms? Rent provision in an emerging financial market, The Quarterly Journal of Economics, 120(4), 1371-1411.

La Porta, R., and F. Lopez-de-Silanes, 1999, The benefits of privatization: Evidence from Mexico, The Quarterly Journal of Economics, 114(4), 1193-1242.

Ljungqvist, A., D. Chen, D. Jiang, H. Lu, and M. Zhou, 2017, State capitalism vs. private enterprise, Working paper.

Megginson, W.L., R.C. Nash, and M. Randenborgh, 1994, The financial and operating performance of newly privatized firms: An international empirical analysis, The Journal of Finance, 49(2), 403-452.

Moore, W.H., 2000, The repression of dissent: A substitution model of government coercion, Journal of Conflict Resolution , 44(1), 107-127.

Musacchio, A., and S.G. Lazzarini, 2014, Reinventing state capitalism, Harvard University Press.

Musacchio, A., S.G. Lazzarini, and R.V. Aguilera, 2015, New varieties of state capitalism: Strategic and governance implications, The Academy of Management Perspectives ,29(1), $115-131$. 
Shleifer, A., 1998, State versus private ownership, Journal of Economic Perspectives, 12(4), $133-150$.

Shleifer, A., and R.W. Vishny, 1994, Politicians and firms, The Quarterly Journal of Economics, 109(4), 995-1025.

Shleifer, A., and R.W. Vishny, 1998, The grabbing hand: Government pathologies and their cures, Cambridge, MA: Harvard University Press.

Shin, H., and R. Stulz, 1998, Are internal capital markets efficient?, The Quarterly Journal of Economics, 113(2), 531-552.

Tanner, M.S., 2014, China's social unrest problem, Testimony before the U.S.-China Economic and Security Review Commission.

Walter, B.F., 2006, Building reputation: Why governments fight some separatists but not others, American Journal of Political Science, 50(2), 313-330.

Wei, J., 2015, Tibet as recipient of assistance and its sustainable development, China Policy Institute Policy Paper, No. 9. 


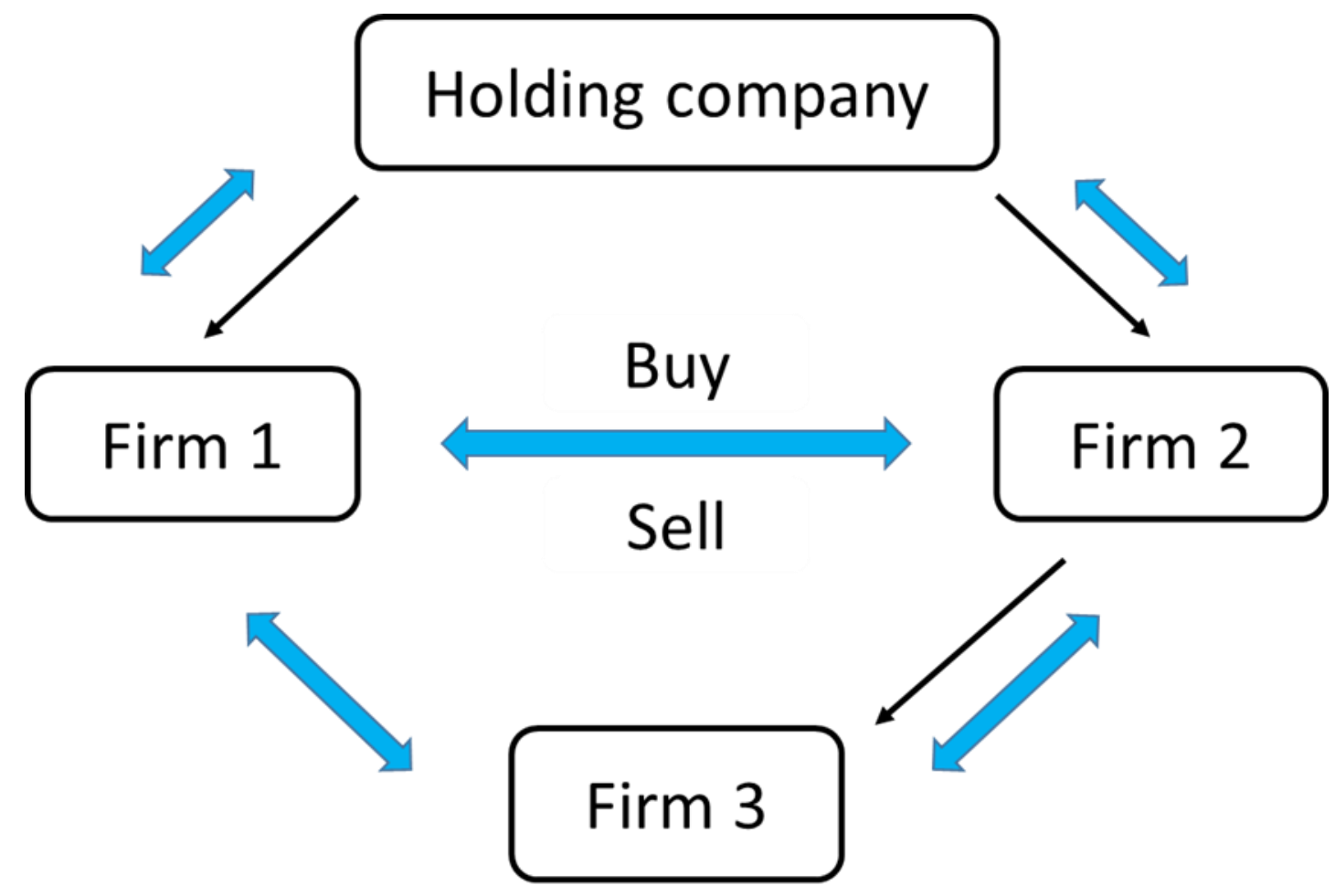

Figure 1 Hypothetical business group structure and related party transactions

The black arrows represent the direction of ownership, and blue arrows depict the direction of potential related party transactions. In my sample, I focus on transactions that involve listed firms for limited information on non-listed firms. Relevant information on related party transactions includes trade entities, cash flow, trading targets, announcement dates, trade dates, pricing rules, etc. 


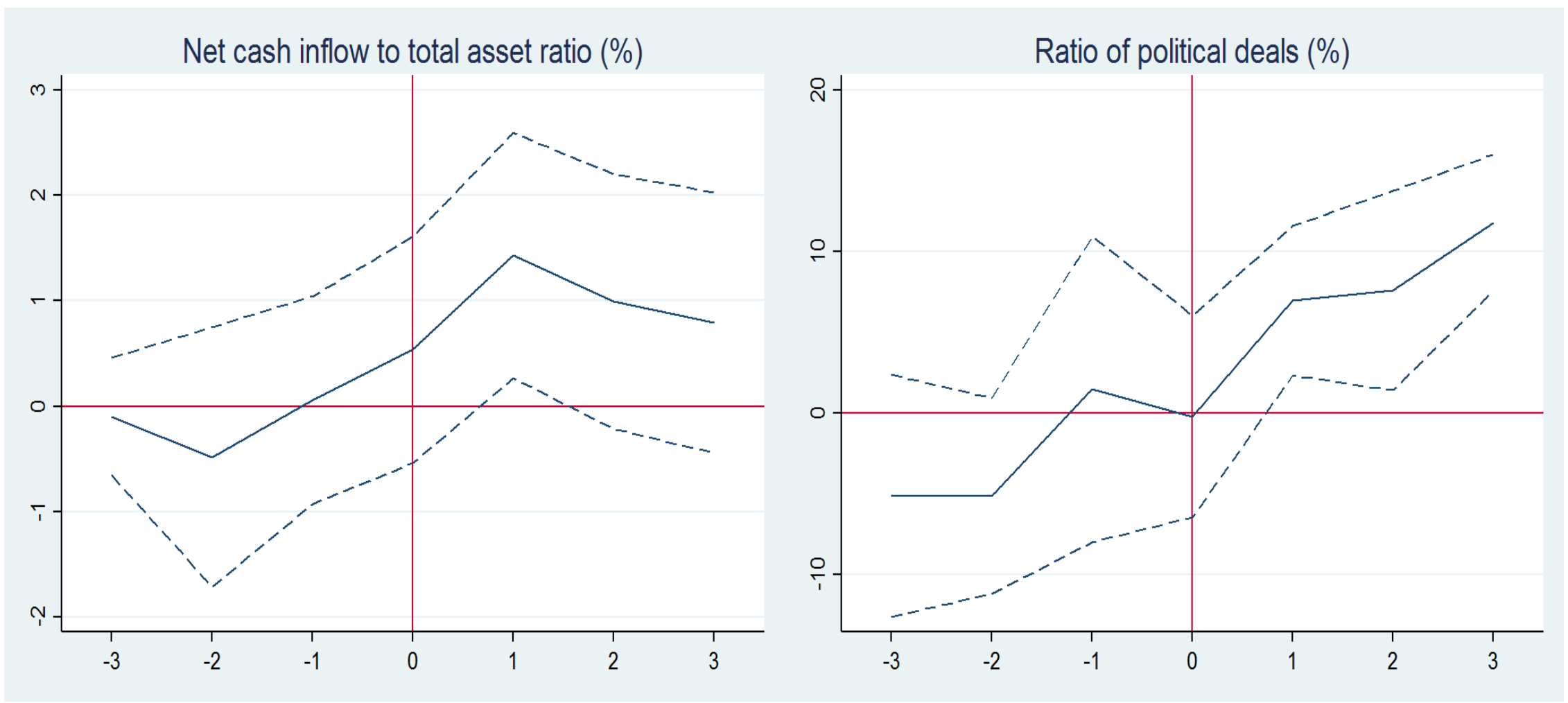

Figure 2 Resource allocation by quarter

This figure plots the coefficient estimates from regressing the two measures of resource allocation (net cash inflow to total asset ratio, and the ratio of political deals) on an indicator for treatment. The regression follows a modified version of equations (1') and (2), where I introduce the cohort dimension to create control groups for each individual event and alter the fixed effects as year-by-cohort, firm-by-cohort, and area-by-quarter-by-cohort fixed effects. 
Table 1 Adverse Shocks to Regional Stability

The table lists eight adverse shocks to regional stability. They can be classified into 3 categories: (1) territorial disputes, 2) socioeconomic conflicts, and (3) ethnic conflicts.
Category
Time
Event
Affected Area
Description
Nature
Notes

\section{Territorial dispute: China vs. Japan \\ $2010 q 3$ clashed near \\ Senkaku/Diaoyu \\ Islands}

Fujian

A PRC fishing trawler allegedly collided with a Japanese coast guard ship north of the disputed islands. The Chinese crew was arrested, resulting in the cancellation of bilateral dialog.

\author{
Carrot "Rising tension" \\ -BBC, Sept. 8, 2010
}

The Japanese government purchased the island on September 11, which invited strong protests from the Chinese. Six more Chinese Marine Surveillance

Japanese government

Territorial dispute: China vs. Japan

$2012 q 3$ nationalized

Senkaku/Diaoyu

Islands

Fujian patrols were sent to the disputed areas. The Chinese government further condoned a boycott of Japanese products and suspended the 40th anniversary of Sino-Japanese relations.
"The most serious for SinoJapanese relations in the post-

Carrot war period in terms of the risk of militarized conflict." —BBC, Feb. 8, 2013
High-ranking government politician; party chief of Chongqing; legacy of Bo Yibo, a top 25 senior party official; high

Socioeconomic conflict: 2012q1 Bo Xilai incident

Political scandal

\section{Chongqing}

flyer tipped for top office. He and his family were prosecuted on charges of bribery, abuse of power, corruption, and murder.

Car bomb suicide attack initiated by the

Ethnic conflict: Uighur-Han 2013q4 Car bomb in Tiananmen Square
East Turkestan Islamic Movement, or Turkistan Islamic Party; 5 killed, 38 injured.

\author{
Carrot scandal" \\ -BBC, Nov. 11, 2013 \\ "Major incident" \\ - CN government \\ "Unstable society" \\ Carrot -Yomiuri Shimbun \\ Attack "in the most politically \\ sensitive place in China" \\ -BBC, Oct. 30, 2013
}




\begin{tabular}{|c|c|c|c|c|}
\hline $\begin{array}{l}\text { Ethnic conflict: } \\
\text { Uighur-Han }\end{array}$ & $2014 q 1$ & $\begin{array}{l}\text { Random attack in } \\
\text { public areas }\end{array}$ & $\begin{array}{l}\text { Kunming, } \\
\text { Changsha, } \\
\text { Huaihua, and } \\
\text { Guangzhou }\end{array}$ & $\begin{array}{l}\text { Violent attacks in public areas by the } \\
\text { East Turkestan Islamic Movement, or } \\
\text { Turkistan Islamic Party. }\end{array}$ \\
\hline
\end{tabular}

\begin{tabular}{|c|c|c|c|c|}
\hline $\begin{array}{l}\text { Ethnic conflict: } \\
\text { Tibet-Han }\end{array}$ & $2010 q 4$ & $\begin{array}{l}\text { Education reform in } \\
\text { Tibetan schools }\end{array}$ & Qinghai & $\begin{array}{l}\text { Over } 9,000 \text { students protest against } \\
\text { language-education reform promoting Carrot } \\
\text { Mandarin over Tibetan. }\end{array}$ \\
\hline
\end{tabular}

\begin{tabular}{|c|c|c|c|c|c|c|}
\hline $\begin{array}{l}\text { Ethnic conflict: } \\
\text { Tibet-Han }\end{array}$ & $2008 q 1$ & Mar. 14, Tibet riot & $\begin{array}{c}\text { Tibet, and } \\
\text { Aba }\end{array}$ & $\begin{array}{l}\text { Starts with street protests by monks and } \\
\text { later descends into rioting, burning, } \\
\text { looting, and ethnic killing of Hui and } \\
\text { Han; } 18 \text { killed, } 382 \text { injured. }\end{array}$ & Stick & $\begin{array}{l}\text { World attention, massive } \\
\text { protest against Beijing } \\
\text { Olympics }\end{array}$ \\
\hline $\begin{array}{l}\text { Ethnic conflict: } \\
\text { Uighur-Han }\end{array}$ & $2009 q 2$ & July 5, Urumqi riot & Urumqi & $\begin{array}{l}\text { Protests turn violent when thousands of } \\
\text { Uighurs attack Han and rampage through } \\
\text { Urumqi. According to state media, the } \\
\text { riots left } 197 \text { people dead and } 1,721 \\
\text { injured, while the World Uighur Congress } \\
\text { (WUC) estimates that as many as } 600 \\
\text { died. }\end{array}$ & Stick & \\
\hline
\end{tabular}


Table 2 Summary Statistics

Panel A reports a summary of statistics on related party transactions in my sample; all figures are expressed in thousands of Chinese yuan in Panel A. Panel B provides a summary of statistics for variables at the firm level; all figures are expressed in millions of Chinese yuan.

\begin{tabular}{|c|c|c|c|c|c|}
\hline \multicolumn{6}{|c|}{ A. Related Party Transaction (Chinese Yuan 1000) } \\
\hline & $\mathbf{N}$ & Mean & St. dev. & Min & Max \\
\hline Transaction amount & 244,723 & 123,329 & 359,258 & 3 & $2,742,000$ \\
\hline \multicolumn{6}{|c|}{ B. Firm-Level Variables (Chinese Yuan 1 million) } \\
\hline & $\mathbf{N}$ & Mean & St. dev. & Min & Max \\
\hline Net cash inflow to firm assets (\%) & 63,002 & -0.03 & 7 & -28 & 30 \\
\hline Political deal ratio $(\%)$ & 64,262 & -0.80 & 54 & -100 & 100 \\
\hline Number of employees & 75,179 & 2,715 & 3,447 & 145 & 14,137 \\
\hline Total labor payment & 67,860 & 119 & 841 & .33 & 40,302 \\
\hline Capital expenditure & 65,175 & 153 & 1,880 & 0 & 132,114 \\
\hline Book-to-market ratio & 60,506 & 0.92 & 1.32 & 0.10 & 26 \\
\hline Firm assets & 63,008 & 8,098 & 26,687 & 150 & 265,557 \\
\hline Firm equity & 61,719 & 2,982 & 6,577 & 0 & 58,912 \\
\hline Leverage (\%) & 62,607 & 17 & 16 & 0 & 68 \\
\hline Cash-to-firm assets (\%) & 63,000 & 20 & 16 & 0.13 & 72 \\
\hline Return on assets (\%) & 62,997 & 3 & 5 & -15 & 19 \\
\hline
\end{tabular}


Table 3 Resource Allocation at Adverse Shocks-SOEs and Non-SOEs

The table reports the estimates of:

$$
\text { Resource allocation }_{f q}=\alpha_{f}+\alpha_{q}+\alpha_{\text {area }, q o y}+\beta \text { Treated }_{f q}+\gamma^{\prime} x_{f q}+\varepsilon_{f q}
$$

In panel $\mathrm{A}$, the dependent variable is the total net cash inflow scaled by the total assets of firm $f$ in quarter $q$. In panel $\mathrm{B}$, the dependent variable is the percentage of net off-market-priced deals (political deals) of firm $f$ in quarter $q$. On the right hand side, Treated is a continuous treated variable equal to 1 in the four quarters after an adverse shock breaks out in a city where firms are located, and $x$ is a vector of control variables, including the natural logarithm of firm equity, return on assets, leverage ratio, cash-to-assets ratio, the natural logarithm of local GDP, population, and government fiscal expenses. Columns (1)-(2) report results based on "carrot" events for SOEs and non-SOEs, respectively. Columns (3)-(4) report results based on "stick" events for SOEs and non-SOEs, respectively. All columns include firm fixed effects, quarter fixed effects, and the product of economic zones and quarter of the year fixed effects. All variables are defined in detail in Appendix A. Standard errors, reported in parentheses, are clustered at the city and quarter levels. The symbols *, **, and $* * *$ denote statistical significance at the $10 \%, 5 \%$, and $1 \%$ levels respectively.

\begin{tabular}{|c|c|c|c|c|}
\hline \multicolumn{5}{|c|}{ Panel A } \\
\hline Net flow / total assets & \multicolumn{2}{|c|}{ Carrot Events } & \multicolumn{2}{|c|}{ Stick Events } \\
\hline \multirow{4}{*}{ Treated $_{f q}$} & (1) & (2) & (3) & (4) \\
\hline & SOE & Non-SOE & SOE & Non-SOE \\
\hline & $0.858 * *$ & 0.167 & $-0.489 *$ & -0.271 \\
\hline & $(0.36)$ & $(0.21)$ & $(0.24)$ & $(0.38)$ \\
\hline Controls & $\mathrm{Y}$ & Y & Y & $\mathrm{Y}$ \\
\hline Quarter f.e. & Y & $\mathrm{Y}$ & $\mathrm{Y}$ & $\mathrm{Y}$ \\
\hline Firm f.e. & $\mathrm{Y}$ & $\mathrm{Y}$ & $\mathrm{Y}$ & $\mathrm{Y}$ \\
\hline Area $\times$ QoY f.e. & $\mathrm{Y}$ & $\mathrm{Y}$ & $\mathrm{Y}$ & $\mathrm{Y}$ \\
\hline $\mathrm{N}$ & 15,932 & 29,693 & 8,024 & 8,501 \\
\hline $\mathrm{R}^{2}$ & 0.21 & 0.20 & 0.18 & 0.17 \\
\hline \multicolumn{5}{|c|}{ Panel B } \\
\hline Political deals / total deals & \multicolumn{2}{|c|}{ Carrot Events } & \multicolumn{2}{|c|}{ Stick Events } \\
\hline \multirow{4}{*}{ Treated $_{f q}$} & (1) & (2) & (3) & (4) \\
\hline & SOE & Non-SOE & SOE & Non-SOE \\
\hline & $7.329 * * *$ & 0.755 & $-8.019 * *$ & -0.795 \\
\hline & (1.93) & $(1.47)$ & $(2.99)$ & $(5.76)$ \\
\hline Controls & $\mathrm{Y}$ & Y & $\mathrm{Y}$ & $\mathrm{Y}$ \\
\hline Quarter f.e. & $\mathrm{Y}$ & $\mathrm{Y}$ & $\mathrm{Y}$ & $\mathrm{Y}$ \\
\hline Firm f.e. & $\mathrm{Y}$ & $\mathrm{Y}$ & $\mathrm{Y}$ & $\mathrm{Y}$ \\
\hline Area $\times$ QoY f.e. & $\mathrm{Y}$ & $\mathrm{Y}$ & $\mathrm{Y}$ & $\mathrm{Y}$ \\
\hline $\mathrm{N}$ & 15,932 & 29,693 & 8,024 & 8,501 \\
\hline $\mathrm{R}^{2}$ & 0.29 & 0.25 & 0.24 & 0.26 \\
\hline
\end{tabular}


Table 4 Labor Costs, Employees, Investment Decisions, and Resource Allocation

The table reports the estimates of:

$$
\text { Firm policy }_{f q}=\alpha_{f}+\alpha_{q}+\alpha_{\text {area }, q o y}+\beta_{0} \text { Treated }_{f q} \times \Delta \text { Cash }_{f}+\beta_{1} \text { Treated }_{f q}+\gamma^{\prime} x_{f q}+\varepsilon_{f q}
$$

The sample contains both "carrot" and "stick" events. The dependent variable is the natural logarithm of labor payments (columns (1)-(2)), the logamount of capital expenditure (columns (3)-(4)), or log-number of employees (columns (5)-(6)) in firm $f$ in quarter $q$. On the right-hand side, Treated is a continuous treated variable equal to 1 in the four quarters after an adverse shock breaks out in a city where firms are located. $\Delta c a s h$ is the change in the median of net cash inflow to total asset ratio between event period and event-free period for firm $f$. All specifications include $x$, which is a vector of control variables used in Table 3. Columns (1), (3), and (5) report results for SOEs. Columns (2), (4), and (6) report results for non-SOEs. All columns include firm fixed effects, quarter fixed effects, and the product of economic zones and quarter of the year fixed effects. All variables are defined in detail in Appendix A. Standard errors, reported in parentheses, are clustered at the city and quarter levels. The symbols *, **, and *** denote statistical significance at the $10 \%, 5 \%$, and $1 \%$ levels respectively.

\begin{tabular}{|c|c|c|c|c|c|c|}
\hline \multirow[t]{2}{*}{ Dep. variable: } & \multicolumn{2}{|c|}{$\log (1+$ Labor payment $)$} & \multicolumn{2}{|c|}{$\log (1+$ Capital expenditure $)$} & \multicolumn{2}{|c|}{$\log (1+$ No.of employees $)$} \\
\hline & (1) & (2) & (3) & (4) & (5) & (6) \\
\hline & SOE & Non-SOE & SOE & Non-SOE & SOE & Non-SOE \\
\hline \multirow[t]{2}{*}{ Treated $_{f q} \times \Delta$ cash $_{f}$} & $0.040 * *$ & -0.001 & $0.045^{* *}$ & 0.005 & $0.007 * *$ & 0.004 \\
\hline & $(0.02)$ & $(0.01)$ & $(0.02)$ & $(0.02)$ & $(0.00)$ & $(0.00)$ \\
\hline \multirow[t]{2}{*}{ Treated $_{f q}$} & $0.013^{*}$ & $0.040 * *$ & $0.111 *$ & -0.010 & $0.054 * * *$ & $0.057 * * *$ \\
\hline & $(0.01)$ & $(0.02)$ & $(0.06)$ & $(0.03)$ & $(0.01)$ & $(0.02)$ \\
\hline Controls & $\mathrm{Y}$ & $\mathrm{Y}$ & $\mathrm{Y}$ & $\mathrm{Y}$ & $\mathrm{Y}$ & $\mathrm{Y}$ \\
\hline Quarter f.e. & $\mathrm{Y}$ & $\mathrm{Y}$ & $\mathrm{Y}$ & $\mathrm{Y}$ & Y & $\mathrm{Y}$ \\
\hline Firm f.e. & Y & Y & $\mathrm{Y}$ & $\mathrm{Y}$ & $\mathrm{Y}$ & $\mathrm{Y}$ \\
\hline Area $\times$ QoY f.e & $\mathrm{Y}$ & $\mathrm{Y}$ & $\mathrm{Y}$ & Y & Y & Y \\
\hline $\mathrm{N}$ & 21,999 & 35,401 & 21,338 & 33,881 & 22,003 & 35,418 \\
\hline $\mathrm{R}^{2}$ & 0.90 & 0.87 & 0.72 & 0.62 & 0.90 & 0.90 \\
\hline
\end{tabular}




\section{Table 5 Firm Value and Resource Allocation}

The table reports the estimates of:

$$
\text { Book to market ratio } f q=\alpha_{f}+\alpha_{q}+\alpha_{\text {area }, q o y}+\beta_{0} \text { Treated }_{f q} \times \Delta \text { Cash }_{f}+\beta_{1} \text { Treated }_{f q}+\gamma^{\prime} x_{f q}+\varepsilon_{f q}
$$

The sample contains both "carrot" and "stick" events. The dependent variable is the book-to-market ratio of firm $f$ in quarter $q$. On the right-hand side, Treated is a continuous treated variable equal to 1 in the four quarters after an adverse shock breaks out in a city where firms are located. $\Delta$ cash is the change in the median of net cash inflow to total asset ratio between event period and event-free period for firm $f$, and $x$ is a vector of control variables used in Table 3. Column (1) reports results for SOEs. Column (2) reports results for nonSOEs. All columns include firm fixed effects, quarter fixed effects, and the product of economic zones and quarter of the year fixed effects. All variables are defined in detail in Appendix A. Standard errors, reported in parentheses, are clustered at the city and quarter levels. The symbols *,**, and *** denote statistical significance at the $10 \%, 5 \%$, and $1 \%$ levels respectively.

\begin{tabular}{lcc}
\hline & $(1)$ & $(2)$ \\
& SOE & Non-SOE \\
Treated $_{f q} \times \Delta$ cash $_{f}$ & $0.031^{* *}$ & -0.004 \\
& $(0.01)$ & $(0.01)$ \\
Treated $_{f q}$ & 0.002 & -0.008 \\
& $(0.03)$ & $(0.02)$ \\
& & \\
Controls & $\mathrm{Y}$ & $\mathrm{Y}$ \\
Quarter f.e. & $\mathrm{Y}$ & $\mathrm{Y}$ \\
Firm f.e. & $\mathrm{Y}$ & $\mathrm{Y}$ \\
Area $\times$ QoY f.e. & $\mathrm{Y}$ & $\mathrm{Y}$ \\
$\mathrm{N}$ & 21,540 & 34,168 \\
$\mathrm{R}^{2}$ & 0.81 & 0.79 \\
\hline
\end{tabular}


Table 6 Local sentiment and SOEs payout

The table reports the estimates of:

$$
\text { Sentiment }_{c q}=\alpha_{c}+\alpha_{q}+\alpha_{\text {area,qoy }}+\beta_{0} \text { Treated }_{c q} \times S O E_{c q}+\beta_{1} \text { Treated }_{c q}+\beta_{2} \text { SOE }_{c q}+\gamma^{\prime} x_{c q}+\varepsilon_{c q}
$$

Due to data limitation, the sample only includes the "carrot" events. The dependent variable is the index for local sentiment generated based on the happiness emotion score from the "Weibo Social Moods" data in columns (1)-(4), or the one quarter forward sentiment index in columns (5)-(6). On the right-hand side, Treated is a continuous treated variable equal to 1 in the four quarters after an adverse shock breaks out in a city where firms are located. $S O E$ is a variable measuring the relative operation intensity between SOEs and non-SOEs in cities. It is defined either as a dummy variable that equals 1 if there is any listed SOE in a given city and quarter, or 0 otherwise (columns (1), (2) and (5)), or as a change in the relative intensity of conducting related party transactions between SOEs and non-SOEs in a given city (columns (3), (4) and (6)); $x$ is a vector of local macroeconomic control variables in columns (2), (4) and (6), including the natural logarithm of local GDP, population, and government fiscal expenses. All columns include city fixed effects, quarter fixed effects, and the product of economic zones and quarter of the year fixed effects. All variables are defined in detail in Appendix A. Standard errors, reported in parentheses, are clustered at the city and quarter levels. The symbols *, **, and *** denote statistical significance at the $10 \%$, $5 \%$, and $1 \%$ levels respectively.

\begin{tabular}{|c|c|c|c|c|c|c|}
\hline \multirow[t]{3}{*}{ Dep. Variable: } & \multicolumn{4}{|c|}{ Sentiment } & \multicolumn{2}{|c|}{ One quarter forward Sentiment } \\
\hline & \multicolumn{2}{|c|}{$\operatorname{SOE}(Y / N)$} & \multicolumn{2}{|c|}{$\triangle S O E R P T S$} & \multirow{2}{*}{$\frac{\operatorname{SOE}(Y / N)}{(5)}$} & \multirow{2}{*}{$\frac{\Delta S O E R P T s}{(6)}$} \\
\hline & (1) & (2) & (3) & (4) & & \\
\hline \multirow[t]{2}{*}{ Treated $_{c q} \times S O E_{c q}$} & $0.024 * *$ & $0.023^{*}$ & $0.001 * *$ & $0.001 * *$ & $0.028 * * *$ & $0.002 * * *$ \\
\hline & $(0.01)$ & $(0.01)$ & $(0.00)$ & $(0.00)$ & $(0.01)$ & $(0.00)$ \\
\hline \multirow[t]{2}{*}{ Treated $_{c q}$} & $-0.020 *$ & $-0.020 *$ & -0.004 & -0.004 & $-0.023 * *$ & -0.003 \\
\hline & $(0.01)$ & $(0.01)$ & $(0.01)$ & $(0.01)$ & $(0.01)$ & $(0.00)$ \\
\hline \multirow[t]{2}{*}{$S O E_{c q}$} & -0.106 & -0.103 & - & - & -0.005 & - \\
\hline & $(0.08)$ & $(0.08)$ & - & - & $(0.01)$ & - \\
\hline \multirow[t]{2}{*}{ Sentiment $_{c q}$} & - & - & - & - & $0.160 * * *$ & $0.162 * * *$ \\
\hline & - & - & - & - & $(0.05)$ & $(0.05)$ \\
\hline Controls & $\mathrm{N}$ & $\mathrm{Y}$ & $\mathrm{N}$ & $\mathrm{Y}$ & $\mathrm{Y}$ & $\mathrm{Y}$ \\
\hline Quarter f.e. & Y & Y & $\mathrm{Y}$ & $\mathrm{Y}$ & $\mathrm{Y}$ & Y \\
\hline City f.e. & $\mathrm{Y}$ & $\mathrm{Y}$ & $\mathrm{Y}$ & $\mathrm{Y}$ & $\mathrm{Y}$ & $\mathrm{Y}$ \\
\hline Area $\times$ QoY f.e. & $\mathrm{Y}$ & Y & $\mathrm{Y}$ & $\mathrm{Y}$ & $\mathrm{Y}$ & Y \\
\hline $\mathrm{N}$ & 4,541 & 4,541 & 2,311 & 2,311 & 4,326 & 2,203 \\
\hline $\mathrm{R}^{2}$ & 0.38 & 0.39 & 0.32 & 0.33 & 0.38 & 0.32 \\
\hline
\end{tabular}




\section{Appendix}


Appendix A. Variable Definitions

Variable

Net inflow

Ratio of political deals

Labor payments

Capital expenditure

Number of employees

Book-to-market ratio

Sentiment

City

Post

Firm assets

Firm equity

Return on assets

Leverage ratio

Cash-to-assets ratio

SOE $(Y / N)$

SOE RPTS

Unrest

Civil affairs cost to GDP ratio

Ratio of guarantees deals

Central

\section{Definition}

The sum of net inflow of cash generated by related party transactions for firm $f$ in a given quarter $q$

The ratio of the net number of political deals that bring in funds over total number of deals for firm $f$ in a given quarter $q$

The total cost of employees for firm $f$ in a given quarter $q$

The total amount of gross capital expenditure in firm $f$ in a given quarter $q$

The total number of employees in firm $f$ in a given quarter $q$

The book to market ratio of firm $f$ in a given quarter $q$

The keyword score of Happiness scaled by the number of Happiness keywords and the total number of posts in a given quarter $q$ Sentiment $_{c q}$

$$
=\frac{\text { Happy keyword } \text { score }_{c q}}{\text { no.of Happy keywords } s_{c q} \times \text { total no. of posts }_{c q}}
$$

Dummy variable that equals 1 if firm $f$ is located in shock-area(s), or 0 otherwise

Time dummy variable that equals 1 in the four quarters following each shock, and 0 otherwise.

Total assets of firm $f$ in a given quarter $q$

Total equity of firm $f$ in a given quarter $q$

The ratio of total profits to total assets of firm $f$ in a given quarter $q$

The ratio of the sum of short-term and long-term debt to total assets of firm $f$ in a given quarter $q$

The ratio of the cash holdings to total assets of firm $f$ in a given quarter $q$

Dummy variable that equals 1 if there is at least $1 \mathrm{SOE}$ located in a city $c$ quarter $q$, or 0 otherwise

The relative intensity of related party transactions conducted between SOEs and non-SOEs in a city $c$

The natural logarithm of the number of labor conflicts and terrorist attacks in a city $c$, quarter $q$

The ratio of civil affairs costs to local GDP at province $p$, year $y$. The civil affairs costs include government expenditures on social welfare, minimum living allowance, settlement funds, etc.

The ratio of number of net guarantees deals that bring in funds to the total number of deals for firm $f$ in a given quarter $q$

Dummy variable that equals 1 if a $\mathrm{SOE}$ is owned by the central 
Monopoly

$\Delta$ Cash

Local population

Local GDP

Local fiscal expenditure government, or 0 otherwise

Dummy variable that equals 1 if a firm belongs to the 13 sectors that are classified as state monopoly sectors, or 0 otherwise. The 13 sectors include 1) oil and gas exploration, 2) tobacco, 3) petroleum processing, 4) coking and nuclear fuel processing, 5) electricity, heat production and supply, 6) gas production and supply, 7) water production and supply, 8) railway transport, 9) postal service, 10) telecommunications and other information transmission services, 11) financial services, 12) non-ferrous metals exploration and processing, and 13) ferrous metal exploration and processing.

The change in funds received by firm $f$ around a shock. It is computed by taking the first difference of the medians of the net cash inflow to total assets ratio in firm $f$ in shock- and non-shock periods.

$$
\begin{aligned}
& \left.\Delta \text { Cash }_{f}=\text { Median }_{\left(\frac{\text { Net inflow }_{f q}}{\text { Total assets }_{f q}}\right.}, \text { Post }_{q}=1\right)- \\
& \text { Median }\left(\frac{\text { Net inflow }_{f q}}{\text { Totalassets }_{f q}}, \text { Post }_{q}=0\right)
\end{aligned}
$$

Annual population statistics at the province level

Annual GDP statistics at the city level

Annual government fiscal-expenditure statistics at the city level 
Table B.1 Resource Allocation at Adverse Shocks- Heterogeneous Effects among SOEs

The table reports the estimates following specifications in Table 3 with additional variables Central and the interaction term Treated $\times$ Central in columns (1) and (3), and Monopoly and the interaction term Treated $\times$ Monopoly in columns (2) and (4). All variables are defined in detail in Appendix A. Standard errors, reported in parentheses, are clustered at the city and quarter levels. The symbols $* * *$, and $* * *$ denote statistical significance at the $10 \%, 5 \%$, and $1 \%$ levels respectively.

\begin{tabular}{|c|c|c|c|c|}
\hline \multicolumn{5}{|c|}{ Panel A } \\
\hline \multirow[t]{2}{*}{ Net flow / total assets } & \multicolumn{2}{|c|}{ Carrot Events } & \multicolumn{2}{|c|}{ Stick Events } \\
\hline & (1) & (2) & (3) & (4) \\
\hline & SOE & SOE & SOE & SOE \\
\hline \multirow[t]{2}{*}{ Treated $_{f q}$} & $0.865^{* *}$ & $0.960 *$ & -0.658 & -0.422 \\
\hline & $(0.42)$ & $(0.54)$ & $(0.57)$ & $(0.25)$ \\
\hline \multirow[t]{2}{*}{ Treated $_{f q} \times$ Central $_{f}$} & -0.054 & & 1.118 & \\
\hline & $(0.67)$ & & $(1.15)$ & \\
\hline \multirow[t]{2}{*}{ Treated $_{f q} \times$ Monopoly $_{f}$} & & -0.383 & & -0.427 \\
\hline & & $(0.74)$ & & $(0.81)$ \\
\hline Controls & $\mathrm{Y}$ & $\mathrm{Y}$ & $\mathrm{Y}$ & $\mathrm{Y}$ \\
\hline Quarter f.e. & $\mathrm{Y}$ & $\mathrm{Y}$ & $\mathrm{Y}$ & $\mathrm{Y}$ \\
\hline Firm f.e. & Y & $\mathrm{Y}$ & Y & $\mathrm{Y}$ \\
\hline Area $\times$ QoY f.e. & $\mathrm{Y}$ & $\mathrm{Y}$ & Y & $\mathrm{Y}$ \\
\hline $\mathrm{N}$ & 15,932 & 15,932 & 8,024 & 8,024 \\
\hline $\mathrm{R}^{2}$ & 0.21 & 0.21 & 0.18 & 0.18 \\
\hline \multicolumn{5}{|c|}{ Panel B } \\
\hline \multirow[t]{3}{*}{ Political deals / total deals } & \multicolumn{2}{|c|}{ Carrot Events } & \multicolumn{2}{|c|}{ Stick Events } \\
\hline & (1) & (2) & (3) & (4) \\
\hline & SOE & SOE & SOE & SOE \\
\hline \multirow[t]{2}{*}{ Treated $_{f q}$} & $7.479 * * *$ & $7.966 * * *$ & -11.067 & $-6.616^{*}$ \\
\hline & $(2.42)$ & (1.66) & $(7.78)$ & $(3.36)$ \\
\hline \multirow[t]{2}{*}{ Treated $_{f q} \times$ Central $_{f}$} & -1.204 & & 20.143 & \\
\hline & $(6.31)$ & & $(26.52)$ & \\
\hline \multirow[t]{2}{*}{ Treated $_{f q} \times$ Monopoly $_{f}$} & & -2.386 & & -8.887 \\
\hline & & $(3.77)$ & & $(12.64)$ \\
\hline Controls & $\mathrm{Y}$ & $\mathrm{Y}$ & $\mathrm{Y}$ & $\mathrm{Y}$ \\
\hline Quarter f.e. & $\mathrm{Y}$ & $\mathrm{Y}$ & $\mathrm{Y}$ & $\mathrm{Y}$ \\
\hline Firm f.e. & $\mathrm{Y}$ & $\mathrm{Y}$ & Y & $\mathrm{Y}$ \\
\hline Area $\times$ QoY f.e. & $\mathrm{Y}$ & $\mathrm{Y}$ & $\mathrm{Y}$ & $\mathrm{Y}$ \\
\hline $\mathrm{N}$ & 15,932 & 15,932 & 8,024 & 8,024 \\
\hline $\mathrm{R}^{2}$ & 0.29 & 0.29 & 0.24 & 0.24 \\
\hline
\end{tabular}


Table B.2 Resource Allocation and Future Unrest

The table reports the estimates of:

$$
\text { Unrest }_{c q}=\alpha_{c}+\alpha_{q}+\alpha_{\text {area }, q o y}+\beta_{0} \text { Treated }_{c q} \times S O E_{c q}+\beta_{1} \text { Treated }_{c q}+\beta_{2} S O E_{c q}+\gamma^{\prime} x_{c q}+\varepsilon_{c q}
$$

Due to data limitation, the sample only contains "carrot" events. The dependent variable is the natural logarithm of the number of labor conflicts and terrorist attacks in a city $c$ quarter $q$. The data on labor conflicts is retrieved from the China Labor Bulletin, and data on terrorist attacks is collected from the Global Terrorism Database. On the right-hand side, Treated is a continuous treated variable equal to 1 in the four quarters after an adverse shock breaks out in a city where firms are located. $S O E$ is a variable measuring the relative operation intensity between SOEs and non-SOEs in cities. It is defined either as a dummy variable that equals 1 if there is any listed SOE in a given city and quarter, or 0 otherwise (columns (1)-(3)), or as a change in the relative intensity of conducting related party transactions between SOEs and non-SOEs in a given city (columns (4)-(6)); $x$ is a vector of local macroeconomic control variables including the natural logarithm of local GDP, population, and government fiscal expenses. All columns include city fixed effects, quarter fixed effects, and the product of economic zones and quarter of the year fixed effects. All variables are defined in detail in Appendix A. Standard errors, reported in parentheses, are clustered at the city and quarter levels. The symbols $*, * *$, and $* * *$ denote statistical significance at the $10 \%, 5 \%$, and $1 \%$ levels respectively.

\begin{tabular}{lcccccc}
\hline & & SOE $(Y / N)$ & & \multicolumn{3}{c}{$\Delta$ SOE RPTs } \\
& Unrest $_{c q}$ & Unrest $_{c q+1}$ & Unrest $_{c q+2}$ & Unrest $_{c q}$ & Unrest $_{c q+1}$ & Unrest $_{c q+2}$ \\
& $(1)$ & $(2)$ & $(3)$ & $(4)$ & $(5)$ & $(6)$ \\
Treated $_{f q} \times$ SOE $_{c q}$ & -0.272 & -0.230 & -0.123 & 3.433 & 0.971 & 0.019 \\
& $(0.25)$ & $(0.31)$ & $(0.36)$ & $(13.09)$ & $(14.18)$ & $(0.03)$ \\
Treated $_{f q}$ & 0.161 & 0.187 & 0.108 & 0.028 & 0.066 & 0.049 \\
& $(0.21)$ & $(0.12)$ & $(0.14)$ & $(0.20)$ & $(0.25)$ & $(0.06)$ \\
& & & & & & \\
Controls & $\mathrm{Y}$ & $\mathrm{Y}$ & $\mathrm{Y}$ & $\mathrm{Y}$ & $\mathrm{Y}$ & $\mathrm{Y}$ \\
Quarter f.e. & $\mathrm{Y}$ & $\mathrm{Y}$ & $\mathrm{Y}$ & $\mathrm{Y}$ & $\mathrm{Y}$ & $\mathrm{Y}$ \\
Firm f.e. & $\mathrm{Y}$ & $\mathrm{Y}$ & $\mathrm{Y}$ & $\mathrm{Y}$ & $\mathrm{Y}$ & $\mathrm{Y}$ \\
Area $\times$ QoY f.e. & $\mathrm{Y}$ & $\mathrm{Y}$ & $\mathrm{Y}$ & $\mathrm{Y}$ & $\mathrm{Y}$ & $\mathrm{Y}$ \\
$\mathrm{N}$ & 1,059 & 1,197 & 1,197 & 423 & 484 & 484 \\
$\mathrm{R}^{2}$ & 0.65 & 0.64 & 0.64 & 0.67 & 0.65 & 0.65 \\
\hline
\end{tabular}


Table B.3 Resource Allocation at Adverse Shocks-Individual Events

The table reports the estimates following specification in Table 3. Tests are conducted on individual events without ex ante merging. All variables are defined in detail in Appendix A. Standard errors, reported in parentheses, are clustered at the city level. The symbols *, **, and *** denote statistical significance at the $10 \%, 5 \%$, and $1 \%$ levels respectively.

\begin{tabular}{|c|c|c|c|c|c|c|c|c|}
\hline \multicolumn{9}{|c|}{ Panel A } \\
\hline Net flow / total assets & $\begin{array}{c}\text { Territorial disputes: } \\
\text { China vs. Japan } \\
2010 \mathrm{q} 3 \\
\end{array}$ & $\begin{array}{c}\text { Territorial disputes: } \\
\text { China vs. Japan } \\
2012 \mathrm{q} 3 \\
\end{array}$ & $\begin{array}{c}\text { Bo Xilai incident } \\
2012 q 1\end{array}$ & $\begin{array}{c}\text { Auto bomb on } \\
\text { Tiananmen Square } \\
2013 q 4 \\
\end{array}$ & $\begin{array}{c}\text { Random attack in } \\
\text { public areas } \\
2014 \mathrm{q} 1 \\
\end{array}$ & $\begin{array}{c}\text { Education reform in } \\
\text { Tibetan schools } \\
2010 \mathrm{q} 4 \\
\end{array}$ & $\begin{array}{l}\text { Tibet riot } \\
2008 \mathrm{q} 1\end{array}$ & $\begin{array}{l}\text { Urumqi riot } \\
2009 \mathrm{q} 2\end{array}$ \\
\hline \multirow{4}{*}{ Treated $_{f q}$} & (1) & (2) & (3) & (4) & (5) & (6) & (7) & (8) \\
\hline & SOE & SOE & SOE & SOE & SOE & SOE & SOE & SOE \\
\hline & 1.172 & $1.553 * *$ & $3.425 * * *$ & $0.604 * *$ & 0.116 & $2.345^{* * *}$ & -0.070 & -0.195 \\
\hline & $(0.75)$ & $(0.75)$ & $(0.18)$ & $(0.24)$ & $(0.70)$ & $(0.25)$ & $(0.25)$ & $(0.21)$ \\
\hline Controls & Y & Y & $\mathrm{Y}$ & $\mathrm{Y}$ & $\mathrm{Y}$ & Y & Y & Y \\
\hline Quarter f.e. & $\mathrm{Y}$ & $\mathrm{Y}$ & $\mathrm{Y}$ & $\mathrm{Y}$ & $\mathrm{Y}$ & $\mathrm{Y}$ & $\mathrm{Y}$ & $\mathrm{Y}$ \\
\hline Firm f.e. & $\mathrm{Y}$ & Y & Y & $\mathrm{Y}$ & $\mathrm{Y}$ & $\mathrm{Y}$ & $\mathrm{Y}$ & Y \\
\hline Area $\times$ QoY f.e. & $\mathrm{Y}$ & $\mathrm{Y}$ & $\mathrm{Y}$ & $\mathrm{Y}$ & $\mathrm{Y}$ & $\mathrm{Y}$ & $\mathrm{Y}$ & $\mathrm{Y}$ \\
\hline $\mathrm{N}$ & 5,256 & 5,613 & 5,540 & 5,725 & 5,770 & 5,314 & 4,872 & 5,013 \\
\hline $\mathrm{R}^{2}$ & 0.26 & 0.30 & 0.31 & 0.29 & 0.28 & 0.27 & 0.20 & 0.25 \\
\hline \multicolumn{9}{|c|}{ Panel B } \\
\hline \multicolumn{9}{|c|}{ Political deals / total deals } \\
\hline \multirow{4}{*}{ Treated $_{f q}$} & (1) & (2) & (3) & (4) & (5) & (6) & (7) & (8) \\
\hline & $\mathrm{SOE}$ & SOE & SOE & SOE & SOE & SOE & SOE & SOE \\
\hline & 7.616 & 6.018 & $7.565 * * *$ & $6.270 * * *$ & $12.349 * * *$ & $10.820 * * *$ & $-18.674 * * *$ & $-15.243 * * *$ \\
\hline & $(4.68)$ & $(6.09)$ & (1.54) & $(1.68)$ & $(4.08)$ & $(1.74)$ & $(2.07)$ & $(1.55)$ \\
\hline Controls & $\mathrm{Y}$ & $\mathrm{Y}$ & $\mathrm{Y}$ & $\mathrm{Y}$ & $\mathrm{Y}$ & $\mathrm{Y}$ & $\mathrm{Y}$ & $\mathrm{Y}$ \\
\hline Quarter f.e. & $\mathrm{Y}$ & $\mathrm{Y}$ & $\mathrm{Y}$ & $\mathrm{Y}$ & $\mathrm{Y}$ & $\mathrm{Y}$ & $\mathrm{Y}$ & $\mathrm{Y}$ \\
\hline Firm f.e. & $\mathrm{Y}$ & $Y$ & $\mathrm{Y}$ & $\mathrm{Y}$ & $\mathrm{Y}$ & $\mathrm{Y}$ & $\mathrm{Y}$ & $\mathrm{Y}$ \\
\hline Area $\times$ QoY f.e. & $\mathrm{Y}$ & $\mathrm{Y}$ & $\mathrm{Y}$ & $\mathrm{Y}$ & $\mathrm{Y}$ & $\mathrm{Y}$ & $\mathrm{Y}$ & $\mathrm{Y}$ \\
\hline $\mathrm{N}$ & 5,256 & 5,613 & 5,540 & 5,725 & 5,770 & 5,314 & 4,872 & 5,013 \\
\hline $\mathrm{R}^{2}$ & 0.38 & 0.38 & 0.40 & 0.38 & 0.38 & 0.37 & 0.29 & 0.31 \\
\hline
\end{tabular}


Table B.4 Alternative Policy Tools at Adverse Shocks

The table reports the estimates of:

$$
\text { Alternative channels }_{p y}=\alpha_{p}+\alpha_{y}+\beta_{0} \text { Treated }_{p y}+\varepsilon_{p y}
$$

The sample contains both "carrot" and "stick" events. The dependent variable is the ratio of civil affairs cost to GDP in province $p$, year $y$ in columns (1)-(3). The civil affairs cost is the sum of government expenditures on social welfare, minimum living allowance, settlement funds, etc. On the right-hand side, the continuous treated variable Treated is adapted to the province-year level. It equals 1 in the first year after an adverse shock breaks out in a province. The specification in column (2) includes province fixed effects. The specification in column (3) includes year and province fixed effects. All variables are defined in detail in Appendix A. Standard errors, reported in parentheses, are clustered at the province level. The symbols *,**, and *** denote statistical significance at the $10 \%, 5 \%$, and $1 \%$ levels respectively.

\begin{tabular}{lccc}
\hline \multicolumn{4}{c}{ All Events } \\
\hline Dep. Variable: & \multicolumn{3}{c}{ Civil affairs cost to GDP ratio } \\
\hline \multirow{2}{*}{ Treated $_{p y}$} & $(1)$ & $(2)$ & $(3)$ \\
& $0.141^{*}$ & $0.138^{*}$ & 0.096 \\
Intercept & $(0.07)$ & $(0.07)$ & $(0.07)$ \\
& $0.834^{* * *}$ & $0.359^{* * *}$ & $0.904^{* * *}$ \\
& $(0.08)$ & $(0.00)$ & $(0.02)$ \\
Year f.e. & & & \\
Province f.e. & $\mathrm{N}$ & $\mathrm{N}$ & $\mathrm{Y}$ \\
$\mathrm{N}$ & $\mathrm{N}$ & $\mathrm{Y}$ & $\mathrm{Y}$ \\
$\mathrm{R}^{2}$ & 279 & 279 & 279 \\
\hline
\end{tabular}


Table B.5 Firm Performance and Resource Allocation

The table reports the estimates following specifications in Table 5. The dependent variable is the two-quarter forward return on assets (ROA) of firm $f$ in columns (1)-(2), and the one-year forward ROA of firm $f$ in columns (3)-(4). All variables are defined in detail in Appendix A. Standard errors, reported in parentheses, are clustered at the city and quarter levels. The symbols $*, * *$, and $* * *$ denote statistical significance at the $10 \%$, $5 \%$, and $1 \%$ levels respectively.

Dep. Variable

\begin{tabular}{lcccc} 
& $(1)$ & $(2)$ & $(3)$ & $(4)$ \\
& SOE & Non-SOE & SOE & Non-SOE \\
Treated $_{f q} \times \Delta$ cash $_{f}$ & $0.066^{*}$ & 0.017 & 0.090 & 0.008 \\
& $(0.04)$ & $(0.02)$ & $(0.10)$ & $(0.02)$ \\
Treated $_{f q}$ & 0.120 & $0.183^{* * *}$ & -0.121 & $0.248^{* * *}$ \\
& $(0.08)$ & $(0.02)$ & $(0.16)$ & $(0.07)$ \\
& & & & \\
Controls & $\mathrm{Y}$ & $\mathrm{Y}$ & $\mathrm{Y}$ & $\mathrm{Y}$ \\
Quarter f.e. & $\mathrm{Y}$ & $\mathrm{Y}$ & $\mathrm{Y}$ & $\mathrm{Y}$ \\
Firm f.e. & $\mathrm{Y}$ & $\mathrm{Y}$ & $\mathrm{Y}$ & $\mathrm{Y}$ \\
Area $\times$ QoY f.e. & $\mathrm{Y}$ & $\mathrm{Y}$ & $\mathrm{Y}$ & $\mathrm{Y}$ \\
$\mathrm{N}$ & 21,290 & 33,939 & 19,857 & 30,988 \\
$\mathrm{R}^{2}$ & 0.58 & 0.56 & 0.63 & 0.60 \\
\hline
\end{tabular}


Table B.6 Resource Allocation upon Adverse Shocks—SOEs and Non-SOEs

The table reports the estimates of:

$$
\text { Ratio of guarantees deals } \text { gl }_{q}=\alpha_{f}+\alpha_{q}+\alpha_{\text {area,qoy }}+\beta \text { Treated }_{f q}+\gamma^{\prime} x_{f q}+\varepsilon_{f q}
$$

The dependent variable is the percentage of the net guarantees deals that bring in funds of firm $f$ in quarter $q$. On the right-hand side, Treated is a continuous treated variable equal to 1 in the four quarters after an adverse shock breaks out in a city where firms are located; $x$ is a vector of control variables as in Table 3 . Columns (1)-(2) report results based on "carrot" events for SOEs and non-SOEs, respectively. Columns (3)-(4) report results based on "stick" events for SOEs and non-SOEs, respectively. All columns include firm fixed effects, quarter fixed effects, and the product of economic zones and quarter of the year fixed effects. All variables are defined in detail in Appendix A. Standard errors, reported in parentheses, are clustered at the city and quarter levels. The symbols $*, * *$, and $* * *$ denote statistical significance at the $10 \%, 5 \%$, and $1 \%$ levels respectively.

\begin{tabular}{lcccc}
\hline Guarantees / total deals & \multicolumn{2}{c}{ Carrot Events } & \multicolumn{2}{c}{ Stick Events } \\
\hline & $(1)$ & $(2)$ & $(3)$ & $(4)$ \\
Treated $_{f q}$ & $\mathrm{SOE}$ & Non-SOE & SOE & Non-SOE \\
& $5.580^{* * *}$ & -0.038 & $-7.394^{* *}$ & -1.076 \\
& $(1.90)$ & $(2.23)$ & $(3.32)$ & $(7.39)$ \\
Controls & & & & \\
Quarter f.e. & $\mathrm{Y}$ & $\mathrm{Y}$ & $\mathrm{Y}$ & $\mathrm{Y}$ \\
Firm f.e. & $\mathrm{Y}$ & $\mathrm{Y}$ & $\mathrm{Y}$ & $\mathrm{Y}$ \\
Area $\times$ QoY f.e. & $\mathrm{Y}$ & $\mathrm{Y}$ & $\mathrm{Y}$ & $\mathrm{Y}$ \\
$\mathrm{N}$ & $\mathrm{Y}$ & $\mathrm{Y}$ & $\mathrm{Y}$ & $\mathrm{Y}$ \\
$\mathrm{R}^{2}$ & 15,932 & 29,693 & 8,024 & 8,501 \\
\hline
\end{tabular}




\section{Table B.7 Resource Allocation at Adverse Shocks-More Events}

The table reports the estimates following specifications (1)-(2) in Table 3. Additional social unrest events are included. In total, there are 25 events including peasant protests, labor riots, religion repression, subnational predominance, and social economic protests. All variables are defined in detail in Appendix A. Standard errors, reported in parentheses, are clustered at the city and quarter levels. The symbols *,**, and *** denote statistical significance at the $10 \%, 5 \%$, and $1 \%$ levels respectively.

\begin{tabular}{|c|c|c|}
\hline \multicolumn{3}{|c|}{ Panel A } \\
\hline \multirow{2}{*}{ Net flow / total assets } & \multicolumn{2}{|c|}{ Carrot Events } \\
\hline & (1) & (2) \\
\hline \multirow{3}{*}{ Treated $_{f q}$} & SOE & Non-SOE \\
\hline & $0.585^{* *}$ & 0.164 \\
\hline & $(0.25)$ & $(0.21)$ \\
\hline Controls & $\mathrm{Y}$ & $\mathrm{Y}$ \\
\hline Quarter f.e. & Y & $\mathrm{Y}$ \\
\hline Firm f.e. & Y & $\mathrm{Y}$ \\
\hline Area $\times$ QoY f.e. & Y & Y \\
\hline $\mathrm{N}$ & 20,396 & 35,298 \\
\hline $\mathrm{R}^{2}$ & 0.17 & 0.17 \\
\hline \multicolumn{3}{|c|}{ Panel B } \\
\hline \multirow[t]{2}{*}{ Political deals / total deals } & \multicolumn{2}{|c|}{ Carrot Events } \\
\hline & (1) & (2) \\
\hline \multirow{3}{*}{ Treated $_{f q}$} & SOE & Non-SOE \\
\hline & $5.003 * *$ & 0.317 \\
\hline & $(2.16)$ & $(1.23)$ \\
\hline Controls & Y & $\mathrm{Y}$ \\
\hline Quarter f.e. & Y & $\mathrm{Y}$ \\
\hline Firm f.e. & $\mathrm{Y}$ & $\mathrm{Y}$ \\
\hline Area $\times$ QoY f.e. & $\mathrm{Y}$ & $\mathrm{Y}$ \\
\hline $\mathrm{N}$ & 20,396 & 35,298 \\
\hline $\mathrm{R}^{2}$ & 0.25 & 0.22 \\
\hline
\end{tabular}

